\title{
Acquisition of Letrozole Resistance Through Activation of the p38/MAPK Signaling Cascade
}

\author{
RASHIDRA R. WALKER ${ }^{1}$, KAREN M. GALLEGOS ${ }^{1}$, MELYSSA R. BRATTON ${ }^{2}$, KITANI P. LEMIEUX ${ }^{3}$, \\ KUN ZHANG $^{4}$, GUANGDI WANG $^{5}$, A. MICHAEL DAVIDSON ${ }^{1}$ and SYREETA L. TILGHMAN ${ }^{1}$ \\ ${ }^{1}$ Division of Pharmaceutical Sciences, College of Pharmacy and Pharmaceutical Sciences, \\ Florida A\&M University, Tallahassee, FL, U.S.A.; \\ ${ }^{2}$ Biospecimens Core Laboratory, Louisiana Cancer Research Center, New Orleans, LA, U.S.A.; \\ ${ }^{3}$ Division of Basic Pharmaceutical Sciences, College of Pharmacy, \\ Xavier University of Louisiana, New Orleans, LA, U.S.A.; \\ ${ }^{4}$ Division of Mathematical and Physical Sciences, Department of Computer Science, \\ College of Arts and Sciences, Xavier University of Louisiana, New Orleans, LA, U.S.A.; \\ ${ }^{5}$ Division of Mathematical and Physical Sciences, Department of Chemistry, \\ College of Arts and Sciences, Xavier University of Louisiana, New Orleans, LA, U.S.A.
}

\begin{abstract}
Background/Aim: Previous reports identified a global proteomic signature of estrogen-independent letrozole resistant breast cancer cells, however, it remains unclear how letrozole-resistance is impacted when cells remain estrogen receptor positive (ER+). Materials and Methods: To capture the protein expression profile associated with ER+ Aromatase inhibitor (AI) resistance, a global proteomic analysis was conducted using the letrozole-sensitive (T47Darom cells) and letrozole-resistant cells (T47DaromLR cells). To examine the molecular features associated with this phenotype KaplanMeier analysis, phospho-antibody arrays, proliferation and apoptosis assays were conducted. Results: MAP3K6 was upregulated in the T47DaromLR cells by 3.2-fold $(p<0.01)$ which was associated with a decrease in relapse-free survival among breast cancer patients $(p=0.0019)$. Members of the MAPK/p38 pathway (i.e., phospho-MKK6, phospho-p38, phospho-RSK1, phospho-RSK2, and p70S6K MAPK) were also increased in the T47DaromLR cells, while inhibiting p38 led to decreased proliferation and induction of apoptosis. Conclusion: Activation of the p38/MAPK pathway leads to ER+AI-resistance.
\end{abstract}

This article is freely accessible online.

Correspondence to: Syreeta L. Tilghman, Ph.D., Division of Pharmaceutical Sciences, College of Pharmacy and Pharmaceutical Sciences, Florida A\&M University, 1415 Martin Luther King Jr. Blvd Tallahassee, FL, 32307, U.S.A. Tel: +1 8505993933, e-mail: syreeta.tilghman@famu.edu

Key Words: Breast cancer, letrozole, aromatase inhibitor, resistance, p38, and MAPK.
Aromatase inhibitors, like letrozole, are the first-line therapy for postmenopausal women with estrogen-dependent breast cancer. These agents block the biosynthesis of estrogen through aromatase inhibition and inhibit the proliferation of estrogen-dependent breast tumors. Unfortunately, after several years some patients develop therapeutic resistance, and the tumors continue to proliferate. To study aromatase inhibitor resistance in the laboratory setting, a letrozole resistant cell line was developed by inoculating the MCF-7Ca cells (MCF7 cells stably transfected into the human aromatase gene) into immunocompromised mice and treating the mice with letrozole for 56 weeks (1). After long-term treatment, the tumors acquired resistance to letrozole, were cultured in vitro and termed long term letrozole treated (LTLT)-Ca cells. Previous studies in our lab have demonstrated that as the letrozole-sensitive cells (AC-1) transition to the letrozoleresistant phenotype (LTLT-Ca) they are associated with estrogen independence, up-regulation of growth factor signaling cascades, and increased motility (2). However, the changes that occur as cells acquire resistance to letrozole while maintaining estrogen dependence remains unclear.

To this end, an in vitro model of letrozole resistance was developed whereby the T47D parental cell line was stably transfected with the human aromatase gene and termed the T47Darom cells. The T47Darom cells were treated with letrozole for 75 weeks until they became resistant to letrozole and were called T47DaromLR cells. When the T47DaromLR cells were characterized, they retained both aromatase activity and ER expression (3). As such, this was an ideal model to test the hypothesis that there are distinct proteomic profiles between estrogen-dependent and estrogen-independent letrozole resistant breast cancer cells, 
which may be useful for therapeutic decision making. Here, we examined the proteomic signature associated with T47D cells as they acquire resistance to an aromatase inhibitor.

\section{Materials and Methods}

Cell culture. In this study, we utilized two cell lines previously developed and derived from the T47D parental breast cancer cell line (3). The T47Darom cells (the T47D cells stably transfected with the human aromatase gene) were cultured and maintained in phenol red DMEM media (Invitrogen, Waltham, MA, USA) supplemented with $5 \%$ fetal bovine serum (FBS), penicillinstreptomycin, antimycotic-antibiotic $(10,000 \mathrm{U} / \mathrm{ml}$ penicillin $\mathrm{G}$ sodium; $10,000 \mathrm{mg} / \mathrm{ml}$ streptomycin sulfate), and $0.75 \mathrm{mg} / \mathrm{ml}$ geneticin (Invitrogen). The T47DaromLR cells were generated by treating the T47Darom for 75 weeks in the presence of $10 \mu \mathrm{M}$ letrozole and were maintained in phenol red-free DMEM media (Invitrogen) supplemented with 10\% charcoal-stripped fetal bovine serum (FBS), penicillin-streptomycin, antimycotic-antibiotic $(10,000 \mathrm{U} / \mathrm{ml}$ penicillin $\mathrm{G}$ sodium; $10,000 \mathrm{mg} / \mathrm{ml}$ streptomycin sulfate), $7.5 \mathrm{mg} / \mathrm{ml}$ geneticin (Invitrogen), and $1 \mathrm{mM}$ letrozole (Sigma-Aldrich, St. Louis, MO, USA). The cells were maintained in a tissue culture incubator in a humidified atmosphere of $5 \% \mathrm{CO}_{2}$ and $95 \%$ air at $37^{\circ} \mathrm{C}$. Both cell lines were a generous gift from ITT Research Institute.

MAPK and RTK phosphorylation antibody arrays. To compare the changes in activation/phosphorylation of MAPK and Receptor Tyrosine Kinases (RTK) between the T47Darom and T47DaromLR cells, the Human MAPK Phosphorylation Antibody Array (ab211061, Abcam, Cambridge, MA, USA) and the Human RTK Phosphorylation Antibody Array Membrane (ab193662, Abcam), were evaluated respectively. The antibody arrays consisted of nitrocellulose membranes containing anti-MAPK or anti-RTK antibodies spotted duplicate and include positive and negative controls and a blank. Cell lysates were prepared from T47Darom and T47DaromLR cells using Cell Lysis Buffer supplemented with Phosphatase Inhibitor and Protease Inhibitor Cocktail and stored at $-80^{\circ} \mathrm{C}$ until use. For each cell lysate, $900 \mu \mathrm{g}$ of total protein were determined by the Bradford Assay (BioRad, Hercules, CA, USA) and incubated in $2 \mathrm{ml}$ of $1 \mathrm{X}$ Blocking Buffer at room temperature for $30 \mathrm{~min}$. The antibody array membranes were washed and subsequently incubated with Detection Antibody Cocktail (for MAPK assays) or with biotinylated anti-phosphotyrosine antibody (for RTK assays) overnight at ${ }^{\circ} \mathrm{C}$ to detect phosphorylated cytokines or tyrosine on activated receptors. After washing and incubation with HRP-streptavidin, the membranes were subjected to visualization with chemiluminescence-based detection method.

Cell lysis. T47Darom and T47DaromLR control cells were cultured to $80 \%$ confluence in standard growth medium as described above and washed three times with cold Hank's Buffered Salt Solution (HBSS), then collected with a cell scraper. Nonidet P-40 cell lysis buffer (Invitrogen) containing an additional $1 \mathrm{mM}$ of phenylmethyl sulfonyl fluoride (PMSF) and protease inhibitor mixture (SigmaAldrich) was used to extract total cellular proteins. The concentration of proteins was measured with BCA assay (Pierce Biotechnology, Rockford, IL, USA). The cell lysates were stored at $-80^{\circ} \mathrm{C}$ before further processing.
Trypsin digestion. Protein samples were digested with sequencing grade modified trypsin (Promega Corp, Madison, WI, USA) according to the manufacturer's instructions. Briefly, to aliquots of $100 \mu \mathrm{g}$ of protein sample were added $45 \mu \mathrm{l}$ of $200 \mathrm{mM}$ triethylammonium bicarbonate (TEAB) and the final volume was adjusted to $100 \mu \mathrm{l}$ with ultrapure water. Five microliters of $200 \mathrm{mM}$ Tris (2-carboxyethyl) phosphine (TCEP) were added and the resulting mixture was incubated for $1 \mathrm{~h}$, then $5 \mu \mathrm{l}$ of $375 \mathrm{mM}$ iodoacetamide were added and the mixture was incubated for 30 min in the dark. After incubation, $1 \mathrm{ml}$ of prechilled acetone was added and the precipitation was allowed to proceed overnight. The acetone-precipitated protein pellets were suspended with $100 \mu \mathrm{l}$ of $200 \mathrm{mM}$ TEAB and $2.5 \mu \mathrm{g}$ of trypsin were added to digest the sample overnight at $37^{\circ} \mathrm{C}$.

Tandem mass tags (TMT) labeling. Tandem mass tags TMT6 (Thermo Scientific, Waltham, MA, USA) with different molecular weights (126 131 Da) were applied as isobaric tags for relative and absolute quantification. According to the manufacturer's protocols, the digested samples were individually labeled with TMT6 reagents for $1 \mathrm{~h}$ as follows: three $100-\mu \mathrm{g}$ aliquots of digested peptides from the T47Darom cells were each labeled with a different isobaric tag (TMT126, 127, and 128, respectively). Likewise, $100 \mu \mathrm{g}$ aliquots of peptides from the T47DaromLR cells were labeled with TMT129, 130, and 131 mass tags, respectively. The labeling reaction was quenched with $5 \%$ hydroxylamine. Finally, the six labeled peptide aliquots were combined for subsequent fractionation.

Fractionation of labeled peptide mixture using a strong cation exchange column. The combined TMT labeled peptide mixture was fractionated with a strong cation exchange column (SCX) (Thermo Scientific) on a Shimadzu 2010 HPLC equipped with a UV detector (Shimadzu, Columbus, MD, USA). The mobile phase consisted of buffer A (5 mM KH $\mathrm{PO}_{4}, 25 \%$ acetonitrile, $\left.\mathrm{pH} 2.8\right)$ and buffer B (buffer A plus $350 \mathrm{mM} \mathrm{KCl}$ ). The column was equilibrated with buffer A for 30 min before sample injection. The mobile phase gradient was set as follows at a flow rate of $1.0 \mathrm{ml} / \mathrm{min}$ : (a) 0 to $10 \mathrm{~min}$ : $0 \%$ buffer B; (b) 10 to $40 \mathrm{~min}$ : $0 \%$ to $25 \%$ buffer B, (c) 40 to $45 \mathrm{~min}: 25 \%$ to $100 \%$ buffer B; (d) 45 to 50 min: $100 \%$ buffer B; (e) 50 to 60 min: $100 \%$ to $0 \%$ buffer B; (f) 60 min to 90 min: $0 \%$ buffer B. A total of 60 fractions were initially collected, lyophilized, and combined into 15 final fractions based on SCX chromatographic peaks.

Desalination of fractionated samples. A C18 solid-phase extraction (SPE) column (Hyper-Sep SPE Columns, Thermo-Fisher Scientific) was used to desalt all collected fractions. The combined 15 fractions were each adjusted to $1 \mathrm{ml}$ final volume containing $0.25 \%(\mathrm{v} / \mathrm{v}$ in water) trifluoroacetic acid (TFA, Sigma-Aldrich). The C18 SPE columns were conditioned before use by filling them with $1 \mathrm{ml}$ acetonitrile and allowing the solvent to pass through the column slowly $(\sim 3 \mathrm{~min})$. The columns were then rinsed three times with 1 $\mathrm{ml} 0.25 \%(\mathrm{v} / \mathrm{v}$ in water) TFA solution. The fractions were loaded on to the top of the SPE cartridge and allowed to elute slowly. Columns were washed four times with $1-\mathrm{ml} 0.25 \%$ TFA aliquots before the peptides were eluted with $3 \times 400 \mu \mathrm{l}$ of $80 \%$ acetonitrile/ $0.1 \%$ formic acid (aqueous).

LC-MS/MS analysis on LTQ-Orbitrap. Peptides were analyzed on an LTQ-Orbitrap XL instrument (Thermo-Fisher Scientific) coupled to an Ultimate 3000 Dionex nanoflow LC system (Dionex, 
Sunnyvale, CA, USA). High mass resolution was used for peptide identification and high energy collision dissociation (HCD) was employed for reporter ion quantification. The RP-LC system consisted of a peptide Cap- rap cartridge $(0.5 \times 2 \mathrm{~mm})$ (Michrom BioResources, Auburn, CA, USA) and a prepacked BioBasic C18 PicoFrit analytical column $(75 \mu \mathrm{M}$ i.d. $\times 15 \mathrm{~cm}$ length, New Objective, Woburn, MA, USA) fitted with a For-tisTip emitter tip. Samples were loaded onto the trap cartridge and washed with mobile phase $\mathrm{A}\left(98 \% \mathrm{H}_{2} \mathrm{O}, 2 \%\right.$ acetonitrile, and $0.1 \%$ formic acid) for concentration and desalting. Subsequently, peptides were eluted over $180 \mathrm{~min}$ from the analytical column via the trap cartridge using a linear gradient of $6-100 \%$ mobile phase $\mathrm{B}\left(20 \% \mathrm{H}_{2} \mathrm{O}, 80 \%\right.$ acetonitrile, and $0.1 \%$ formic acid) at a flow-rate of $0.3 \mu \mathrm{l}$ per min using the following gradient: $6 \% \mathrm{~B}$ for $5 \mathrm{~min}$; 6-60\% B for 125 min; $60-100 \%$ B for $5 \mathrm{~min}$; hold at $100 \%$ B for $5 \mathrm{~min}$; $100-6 \%$ B in $2 \mathrm{~min}$; hold at $6 \% \mathrm{~B}$ for $38 \mathrm{~min}$.

The LTQ-Orbitrap tandem mass spectrometer was operated in a data-dependent mode. Briefly, each full MS scan $(60,000$ resolving power) was followed by six MS/MS scans where the three most abundant molecular ions were dynamically selected and fragmented by collision-induced dissociation (CID) using a normalized collision energy of $35 \%$, and the same three molecular ions were also scanned three times by HCD-MS2 with collision energy of $45 \%$. MS scans were acquired in profile mode and MS/MS scans in centroid mode. LTQ-Orbitrap settings were as follows: spray voltage $2.0 \mathrm{kV}, 1$ microscan for MS1 scans at 60,000 resolutions (fwhm at $\mathrm{m} / \mathrm{z}, 400$ ), microscans for MS2 at 7500 resolutions (fwhm at $m / z$ 400); full MS mass range, $m / z$ 400-1400; MS/MS mass range, $m / z, 100-2000$. The "FT master scan preview mode," "Charge state screening", "Monoisotopic precursor selection" and "Charge state rejection" were enabled so that only the $2+, 3+$, and $4+$ ions were selected and fragmented by CID and HCD.

Database search and TMT quantification. The protein search algorithm used was Mascot v2.3.01 (Matrix Science, Boston, MA, USA). Mascot format files were generated by the Proteome Discoverer 1.2 software (Thermo-Fisher Scientific) using the following criteria: database, IPI_Human.fasta. v3.77 (containing 89,422 entries and concatenated with the reversed versions of all sequences.); enzyme, trypsin; maximum missed cleavages, 2; Static modifications, carbamido- methylation (+57 Da), N-terminal TMT6plex (+229 Da), lysyl TMT6plex (+229 Da). Dynamic modifications, N-terminal Clnpyro- Glu (+17 Da); methionine oxidation (+16 Da); STY phosphorylation (+80 Da); Precursor mass tolerance was set at $20 \mathrm{ppm}$; fragment match tolerance was set at $0.8 \mathrm{Da}$. Peptides reported by the search engine were accepted only if they met the false discovery rate of $p<0.05$ (target decoy database), a Mascot ion score $\geq 30$ for peptide identifications was required. For TMT quantification, the ratios of TMT reporter ion abundances in MS/MS spectra generated by HCD (up to six reporter ions ranging from $m / z, 126.12$ to $m / z$ 131.14) from raw data sets were used to calculate fold changes in proteins between control and treatment.

Kaplan-Meier (KM) survival analysis. The application of KM plot has been described in detail previously (4). Briefly, KM plots were obtained using the KM Plotter web-based (kmplot.com/analysis) curator, which surveys public microarray repositories for relapsefree and overall survival among patients with breast, lung, ovarian or gastric cancers. The KM Plotter recognizes 54,675 individual
Affymetrix probe sets, and surveys expression data from 4,142 breast cancer patients (as of 2014). Survival and gene expression data were derived from the GEO (Gene Expression Omnibus), TCGA (The Cancer Genome Atlas), and EGA (European Genomephenome Atlas) databases. In order to ascertain P4HB expression, Affymetrix probe 200654 was selected. Overall Survival in the total population (1402 patients) was determined.

Viability assay. Proliferation assays were performed as previously described (5). Specifically, the T47Darom cells (aromatase inhibitor sensitive) were plated in 96-well plates at a density of $2 \times 10^{3}$ cells per well for each cell line and allowed to recover for $24 \mathrm{~h}$. The T47DaromLR cells (AI-resistant) were cultured in the presence of letrozole. For proliferation assays, the cells were treated with DMSO (control) or $30 \mu \mathrm{M}$ SB205380 in 96-well plates to determine the effects of the various treatments in the absence of letrozole. The resazurin dye (Sigma-Aldrich) was added to each well at $10 \%$ of the total volume and measured at $24 \mathrm{~h}$. The SpectraMax ${ }^{\circledR}$ MiniMax ${ }^{\circledR} 300$ Imaging Cytometer (Molecular Devices, San Jose, CA, USA) was used to measure fluorescence and background wavelengths at $530 \mathrm{~nm}$ and $590 \mathrm{~nm}$ to determine proliferation. All experiments were performed with $\mathrm{n} \geq 3$ and a total of 3 biological replicates were performed. The proliferative activity was calculated as a percent of the vehicle controls as follows:

Antiproliferative activity $=[$ Fluorescence of viable cells (control) Fluorescence of viable cells (treated)]/Fluorescence of viable cells (control).

Caspase 3/7 apoptosis assay. The T47Darom and T47DaromLR cells were seeded at a density of $1.5 \times 10^{3}$ cells in a 96-well plate with appropriate media overnight. Cells were treated the following day with DMSO (control) or $10 \mu \mathrm{M} \mathrm{SB} 205380$. Cells were incubated for $24 \mathrm{~h}$ at $37^{\circ} \mathrm{C}$ with $5 \% \mathrm{CO}_{2}$. On the following day, the cells treated with $4 \mu \mathrm{M}$ CellEvent ${ }^{\mathrm{TM}}$ Caspase-3/7 Green Detection Reagent (Invitrogen) and incubated for $30 \mathrm{~min}$ at $37^{\circ} \mathrm{C}$ with $5 \% \mathrm{CO}_{2}$. The cells were then fixed with $4 \%$ formaldehyde and allowed to incubate for 15 min at room temperature. The SpectraMax ${ }^{\circledR}$ MiniMax ${ }^{\circledR} 300$ Imaging Cytometer (Molecular Devices) was used to measure fluorescence and background wavelengths at $530 \mathrm{~nm}$ and $502 \mathrm{~nm}$, respectively. Cells were imaged on Nikon Ti Eclipse microscope (Minato, Tokyo, Japan) using a FITC filter.

\section{Results}

Proteomic profile of estrogen-dependent letrozole resistant breast cancer cells is associated with a unique signature. To examine the global changes in protein expression as cells transition from AI-sensitive to AI-resistant while maintaining ER expression, a gel-free proteomic approach combining tandem mass tag (TMT) labeling, two-dimensional HPLC, and high-resolution mass spectrometry was utilized. The identities of over 1900 proteins with quantitative abundance ratios were present in both the letrozole sensitive (T47Darom) and the letrozole resistant (T47DaromLR) breast cancer cells. Abundance ratios $\geq 1.25$ were defined as high while those $\leq 0.8$ were defined as low. Of the quantified proteins, a total of 127 were significantly high $(p<0.05)$ as 
indicated by Table I, while 111 were significantly low $(p<0.05)$ as shown by Table II. The top three up-regulated proteins were mitogen-activated kinase kinase kinase 6 (M3K6), protein disulfide isomerase ( $\mathrm{P} 4 \mathrm{HB})$, and midasin (MDN1), and they were increased by 3.204-fold $(p<0.01)$, 3.195 -fold $(p<0.01)$, and 2.759-fold $(p<0.001)$, respectively. These proteins are indicated in bold. Among the downregulated proteins, Peptidyl-prolyl cis-trans isomerase (FKBP4) was decreased by 0.484 -fold $(p<0.001)$ which is also indicated in bold.

High MAP3K6 expression is associated with decreased relapse-free survival. Since MAP3K6 was significantly increased, we sought to examine the clinical relevance on patient survival. To predict whether increased MAP3K6 expression levels were associated with differences in survival, KM Plotter was used to interrogate publicly available microarray repositories of breast cancer patients. Based on these parameters, high MAP3K6 expression was found to be associated with a decrease in relapse-free survival $(p=0.0019)$ with a hazard ratio of $0.84(0.75-0.84)$ (Figure 1$)$.

The MAPK signaling cascade is activated as cells acquire resistance to letrozole. Since M3K6 exhibited the highest increase in expression between the two cell lines, we were interested in determining whether this alteration was associated with activation of the MAPK signaling cascades as a result of ER+ letrozole resistance. To study multiple proteins within this pathway and other receptor tyrosine kinase signaling cascades, the MAPK and RTK phosphoantibody arrays were utilized to measure the activation of key signaling components between the T47Darom and the T47DaromLR cells. We chose both arrays because a previous finding from our group demonstrated that HER2 expression was increased in the T47DaromLR cells (6). Although total HER2 expression was previously shown to be increased, activated ErbB2 (HER2) levels were decreased by 1.40-fold $(p<0.05)$, suggesting this may not be a critical driver associated with ER+ AI resistance (Figure 2). We also observed increased expression of IGF1R which was previously found up-regulated in the LTLT-Ca cells (7). When signaling components associated with the MAPK pathway were assessed, several phosphorylated proteins of interest were significantly increased including MKK6 (1.20fold), p38 (1.41-fold), p70S6K (1.74-fold), phosphoRibosomal S6 Kinase 1 (1.71-fold) and phospho-Ribosomal S6 Kinase 2 (4.74-fold) (Figure 3). This was highly relevant as this pathway is associated with growth, differentiation, apoptosis, and survival. Since there was not a significant change in Akt and mTOR expression, it is unlikely that the $\mathrm{PI} 3 \mathrm{~K} / \mathrm{Akt} / \mathrm{mTOR}$ pathway plays a major role in ER+ acquired AI resistance. Additionally, since both MEK and ERK1 were significantly decreased by 1.43 - and 1.08 -fold

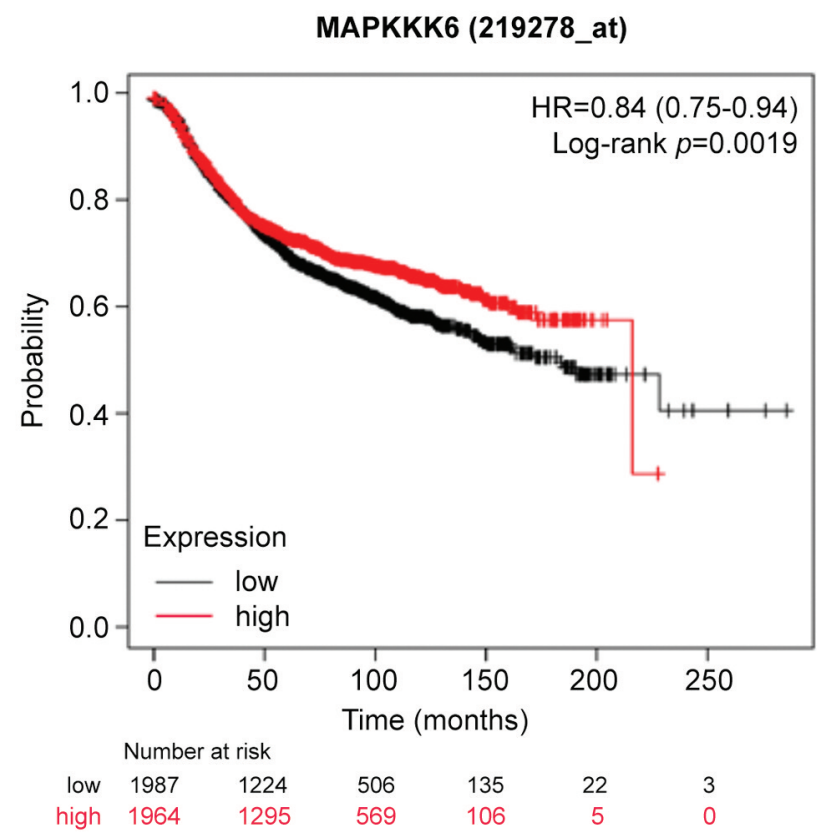

Figure 1. High MAP3K6 expression is associated with decreased relapse-free survival in breast cancer patients. Using Kaplan-Meier Plotter (KM Plotter), publicly available microarray repositories for breast cancer were interrogated to determine whether MAP3K6 expression was associated with different survival rates among breast cancer patients. Hazard ratio (HR) and Log-rank p-values are shown. Low expression (below median) is noted in black, and the high expression (above median) is noted in red.

respectively, the Ras pathway may not be relevant. Taken together, this data suggests the p38/MAPK pathway may be a major driver of ER+ letrozole resistance. It was also noted that there was a 1.43 -fold increase in $\mathrm{p} 53$ expression. This finding was not unusual as the T47D cell line expresses mutant p53 and in cultured cells, overexpression of tumorassociated p53 mutants has been shown to interfere with stress-induced apoptosis, increase resistance to chemotherapeutic drugs (8-12), promote genomic instability (13), and enhance proliferation (14).

The p38/MAPK pathway drives letrozole resistance. Since the proteomic analysis and the antibody array results demonstrated that increased p38/MAPK signaling was associated with the T47DaromLR cells, we wanted to determine whether inhibition of this pathway was responsible, in part, for the refractory nature of the cells as well as their aggressive phenotype. To test this, both the T47Darom and T47DaromLR cells were treated with $30 \mu \mathrm{M}$ SB 203580 (a selective p38 MAPK) and proliferation was measured. Our results demonstrated that while the T47Darom cells were unaffected by SB 203580 treatment, 
Table I. Up-regulated proteins in letrozole resistant T47DaromLR breast cancer cells. Proteomic analyses were performed as described in the Methods section and the ratio of the fold change in T47DaromLR/T47Darom cells is shown. Text in bold indicates the proteins exhibiting the greatest fold change.

\begin{tabular}{|c|c|c|c|c|c|}
\hline Accession & Description & \# AAs & MW [kDa] & Fold change & $\begin{array}{c}t \text {-test } \\
(p \text {-Value })\end{array}$ \\
\hline 095382 & $\begin{array}{l}\text { Mitogen-activated protein kinase } 6 \text { OS=Homo sapiens } \\
\text { GN=MAP3K6 PE }=1 \mathrm{SV}=3 \text { - }[\mathrm{M} 3 \mathrm{~K} 6 \text { _HUMAN] }\end{array}$ & 1,288 & 142.506 & 3.2037514 & $p<0.01$ \\
\hline H0Y3Z3 & $\begin{array}{l}\text { Protein disulfide-isomerase (Fragment) OS=Homo sapiens } \\
\text { GN=P4HB PE }=1 \text { SV=1 - [H0Y3Z3_HUMAN] }\end{array}$ & 274 & 31.5234 & 3.1950322 & $p<0.01$ \\
\hline Q9NU22 & $\begin{array}{l}\text { Midasin OS=Homo sapiens GN=MDN1 PE=1 SV=2 - } \\
\text { [MDN1_HUMAN] }\end{array}$ & 5,596 & 632.42 & 2.7587754 & $p<0.001$ \\
\hline R4GN98 & $\begin{array}{l}\text { Protein S100 (Fragment) OS=Homo sapiens GN=S100A6 PE=1 } \\
\text { SV=1 - [R4GN98_HUMAN] }\end{array}$ & 85 & 9.67506 & 2.6447744 & $p<0.01$ \\
\hline P60903 & $\begin{array}{l}\text { Protein S100-A10 OS=Homo sapiens GN=S100A10 PE=1 } \\
\text { SV=2 - [S10AA_HUMAN] }\end{array}$ & 97 & 11.1955 & 2.5544666 & $p<0.001$ \\
\hline K7EQI0 & $\begin{array}{l}\text { Paragranulin (Fragment) OS=Homo sapiens GN=GRN PE }=4 \\
\mathrm{SV}=1-[\text { K7EQI0_HUMAN] }\end{array}$ & 110 & 11.8242 & 2.4237794 & $p<0.01$ \\
\hline P04083 & $\begin{array}{l}\text { Annexin A1 OS=Homo sapiens GN=ANXA1 PE=1 } \\
\text { SV=2 - [ANXA1_HUMAN] }\end{array}$ & 346 & 38.69 & 2.1587977 & $p<0.001$ \\
\hline E5RG29 & $\begin{array}{l}\text { Aspartyl/asparaginyl beta-hydroxylase (Fragment) } \\
\text { OS=Homo sapiens GN=ASPH PE=4 SV=1 - [E5RG29_HUMAN] }\end{array}$ & 198 & 22.2265 & 2.1382553 & $p<0.01$ \\
\hline H0YA55 & $\begin{array}{l}\text { Serum albumin (Fragment) OS=Homo sapiens GN=ALB } \\
\mathrm{PE}=1 \mathrm{SV}=1 \text { - [H0YA55_HUMAN] }\end{array}$ & 454 & 51.5358 & 2.129391 & $p<0.001$ \\
\hline A0A087WYQ7 & $\begin{array}{l}\text { Kynureninase (Fragment) OS=Homo sapiens GN=KYNU } \\
\mathrm{PE}=1 \mathrm{SV}=1-[\text { A0A087WYQ7_HUMAN] }\end{array}$ & 157 & 17.3711 & 2.0269261 & $p<0.05$ \\
\hline P07476 & $\begin{array}{l}\text { Involucrin OS=Homo sapiens GN=IVL PE }=1 \\
\mathrm{SV}=2 \text { - [INVO_HUMAN] }\end{array}$ & 585 & 68.4372 & 1.9934225 & $p<0.01$ \\
\hline F5H7F6 & $\begin{array}{l}\text { Microsomal glutathione S-transferase } 1 \text { (Fragment) } \\
\text { OS=Homo sapiens GN=MGST1 PE=1 SV=1 - [F5H7F6_HUMAN] }\end{array}$ & $\begin{array}{c}77 \\
2,997\end{array}$ & $\begin{array}{l}8.88048 \\
335.717\end{array}$ & $\begin{array}{l}1.8163795 \\
1.8045951\end{array}$ & $\begin{array}{l}p<0.001 \\
p<0.01\end{array}$ \\
\hline Q9P2D1 & $\begin{array}{l}\text { Chromodomain-helicase-DNA-binding protein } 7 \\
\text { OS=Homo sapiens GN=CHD7 PE=1 SV=3 - [CHD7_HUMAN] }\end{array}$ & & & & \\
\hline O76070 & $\begin{array}{l}\text { Gamma-synuclein OS=Homo sapiens GN=SNCG PE }=1 \\
\text { SV=2 - [SYUG_HUMAN] }\end{array}$ & 127 & 13.3228 & 1.7970365 & $p<0.001$ \\
\hline P07355 & $\begin{array}{l}\text { Annexin A2 OS=Homo sapiens GN=ANXA2 PE }=1 \\
\text { SV=2 - [ANXA2_HUMAN] }\end{array}$ & 339 & 38.5798 & 1.7904175 & $p<0.001$ \\
\hline E9PKU7 & $\begin{array}{l}\text { Neutral alpha-glucosidase AB OS=Homo sapiens GN=GANAB } \\
\mathrm{PE}=1 \mathrm{SV}=1 \text { - [E9PKU7_HUMAN] }\end{array}$ & 852 & 96.4831 & 1.7543555 & $p<0.001$ \\
\hline P31949 & $\begin{array}{l}\text { Protein } \mathrm{S} 100-\mathrm{A} 11 \mathrm{OS}=\overline{\mathrm{H}} \text { omo sapiens } \mathrm{GN}=\mathrm{S} 100 \mathrm{~A} 11 \mathrm{PE}=1 \\
\mathrm{SV}=2-\left[\mathrm{S} 10 \mathrm{AB} \_ \text {HUMAN] }\right.\end{array}$ & 105 & 11.7328 & 1.7525625 & $p<0.01$ \\
\hline P08729 & $\begin{array}{l}\text { Keratin, type II cytoskeletal } 7 \text { OS=Homo sapiens GN=KRT7 } \\
\mathrm{PE}=1 \mathrm{SV}=5-[\mathrm{K} 2 \mathrm{C} 7 \text { HUMAN }]\end{array}$ & 469 & 51.3543 & 1.7525381 & $p<0.001$ \\
\hline Q14019 & $\begin{array}{l}\text { Coactosin-like protein OS=Homo sapiens GN=COTL1 } \\
\mathrm{PE}=1 \mathrm{SV}=3-[\text { COTL1_HUMAN] }\end{array}$ & 142 & 15.935 & 1.7007204 & $p<0.001$ \\
\hline A0A087WUZ6 & $\begin{array}{l}\text { InaD-like protein OS=Homo sapiens GN=INADL PE }=1 \\
\mathrm{SV}=1-\left[\mathrm{A0A087WUZ6 \_ HUMAN]}\right.\end{array}$ & 1,182 & 130 & 1.6896547 & $p<0.001$ \\
\hline P50897 & $\begin{array}{l}\text { Palmitoyl-protein thioesterase } 1 \text { OS=Homo sapiens GN=PPT1 } \\
\mathrm{PE}=1 \mathrm{SV}=1 \text { - [PPT1_HUMAN] }\end{array}$ & 306 & 34.1713 & 1.6864107 & $p<0.001$ \\
\hline R4GN18 & $\begin{array}{l}\text { Membrane cofactor protein (Fragment) OS=Homo sapiens } \\
\text { GN=CD46 PE }=4 \mathrm{SV}=1-[\text { R4GN18_HUMAN] }\end{array}$ & 78 & 8.4965 & 1.636669 & $p<0.001$ \\
\hline P02647 & $\begin{array}{l}\text { Apolipoprotein A-I OS=Homo sapiens GN=APOA1 PE=1 } \\
\text { SV=1 - [APOA1_HUMAN] }\end{array}$ & 267 & 30.7589 & 1.624178 & $p<0.001$ \\
\hline Q8WWA1 & $\begin{array}{l}\text { Transmembrane protein } 40 \text { OS=Homo sapiens GN=TMEM } 40 \\
P E=1 \text { SV=2 - [TMM40_HUMAN] }\end{array}$ & 233 & 25.4793 & 1.6170389 & $p<0.001$ \\
\hline P09467 & $\begin{array}{l}\text { Fructose-1,6-bisphosphatase } 1 \text { OS=Homo sapiens GN=FBP1 } \\
\mathrm{PE}=1 \mathrm{SV}=5 \text { - [F16P1_HUMAN] }\end{array}$ & 338 & 36.8188 & 1.6147259 & $p<0.001$ \\
\hline Q15847 & $\begin{array}{l}\text { Adipogenesis regulatory factor } \mathrm{OS}=\text { Homo sapiens } \\
\text { GN=ADIRF } \mathrm{PE}=1 \mathrm{SV}=1-\left[\mathrm{ADIRF} \_ \text {HUMAN }\right]\end{array}$ & 76 & 7.84997 & 1.6089368 & $p<0.01$ \\
\hline O76062 & $\begin{array}{l}\text { Delta(14)-sterol reductase OS=Homo sapiens GN=TM7SF2 } \\
\mathrm{PE}=2 \mathrm{SV}=3-[\text { ERG24_HUMAN] }\end{array}$ & 418 & 46.3755 & 1.608441 & $p<0.001$ \\
\hline P05026 & $\begin{array}{l}\text { Sodium/potassium-transporting ATPase subunit beta-1 } \\
\text { OS=Homo sapiens GN=ATP1B1 PE=1 SV=1 - [AT1B1_HUMAN] }\end{array}$ & 303 & 35.0389 & 1.6033027 & $p<0.001$ \\
\hline
\end{tabular}


Table I. Continued

\begin{tabular}{|c|c|c|c|c|c|}
\hline Accession & Description & \# AAs & MW [kDa] & Fold change & $\begin{array}{c}t \text {-test } \\
(p \text {-Value })\end{array}$ \\
\hline P12532 & $\begin{array}{l}\text { Creatine kinase U-type, mitochondrial OS=Homo sapiens } \\
\text { GN=CKMT1A PE }=1 \mathrm{SV}=1-\left[\mathrm{KCRU} \_ \text {HUMAN }\right]\end{array}$ & 417 & 47.0072 & 1.595103 & $p<0.001$ \\
\hline P02533 & $\begin{array}{l}\text { Keratin, type I cytoskeletal } 14 \text { OS=Homo sapiens GN=KRT14 } \\
\mathrm{PE}=1 \mathrm{SV}=4-\left[\mathrm{K} 1 \mathrm{C} 14 \_ \text {HUMAN }\right]\end{array}$ & 472 & 51.5294 & 1.5900658 & $p<0.01$ \\
\hline F5H2R5 & $\begin{array}{l}\text { Rho GDP-dissociation inhibitor } 2 \text { (Fragment) OS=Homo sapiens } \\
\text { GN=ARHGDIB PE }=1 \mathrm{SV}=1-[\text { F5H2R5_HUMAN] }\end{array}$ & 88 & 9.78591 & 1.5776326 & $p<0.001$ \\
\hline P30038 & $\begin{array}{l}\text { Delta-1-pyrroline-5-carboxylate dehydrogenase, mitochondrial } \\
\text { OS=Homo sapiens GN=ALDH4A1 PE=1 SV=3 - [AL4A1_HUMAN] }\end{array}$ & 563 & 61.6806 & 1.5699616 & $p<0.001$ \\
\hline J3KQ45 & $\begin{array}{l}\text { Trans-Golgi network integral membrane protein } 2 \text { OS=Homo sapiens } \\
\text { GN=TGOLN2 } \mathrm{PE}=1 \mathrm{SV}=1-[\mathrm{J} 3 \mathrm{KQ} 45 \text { _HUMAN }]\end{array}$ & 454 & 47.8517 & 1.5653502 & $p<0.001$ \\
\hline Q96C23 & $\begin{array}{l}\text { Aldose } 1 \text {-epimerase OS=Homo sapiens GN=GALM PE }=1 \\
\mathrm{SV}=1-\text { [GALM_HUMAN] }\end{array}$ & 342 & 37.7421 & 1.5599502 & $p<0.001$ \\
\hline $\mathrm{O} 15173$ & $\begin{array}{l}\text { Membrane-associated progesterone receptor component } 2 \\
\text { OS=Homo sapiens GN=PGRMC2 } \mathrm{PE}=1 \mathrm{SV}=1-\text { [PGRC2_HUMAN] }\end{array}$ & 223 & 23.8037 & 1.5508404 & $p<0.001$ \\
\hline P14406 & $\begin{array}{l}\text { Cytochrome c oxidase subunit 7A2, mitochondrial } \\
\text { OS=Homo sapiens } \mathrm{GN}=\mathrm{COX} 7 \mathrm{~A} 2 \mathrm{PE}=1 \mathrm{SV}=1-[\mathrm{CX} 7 \mathrm{~A} 2 \text { _HUMAN] }\end{array}$ & 83 & 9.39011 & 1.5499904 & $p<0.001$ \\
\hline F5GYS3 & $\begin{array}{l}\text { Bcl2-associated agonist of cell death OS=Homo sapiens } \\
\text { GN=BAD PE=1 SV=1 - [F5GYS3_HUMAN] }\end{array}$ & 157 & 16.6392 & 1.5392774 & $p<0.01$ \\
\hline Q13011 & $\begin{array}{l}\text { Delta(3,5)-Delta(2,4)-dienoyl-CoA isomerase, mitochondrial } \\
\text { OS=Homo sapiens GN=ECH1 PE=1 SV=2 - [ECH1_HUMAN] }\end{array}$ & 328 & 35.7934 & 1.5385737 & $p<0.01$ \\
\hline P05091 & $\begin{array}{l}\text { Aldehyde dehydrogenase, mitochondrial OS=Homo sapiens } \\
\text { GN=ALDH2 PE=1 SV=2 - [ALDH2_HUMAN] }\end{array}$ & 517 & 56.3456 & 1.5385587 & $p<0.001$ \\
\hline Q5JQF8 & $\begin{array}{l}\text { Polyadenylate-binding protein 1-like } 2 \text { OS=Homo sapiens } \\
\text { GN=PABPC1L2A PE=2 SV=1 - [PAP1M_HUMAN] }\end{array}$ & 200 & 22.7846 & 1.5341699 & $p<0.001$ \\
\hline I3L0Y5 & $\begin{array}{l}\text { ATP synthase } \mathrm{F}(0) \text { complex subunit } \mathrm{C} 1 \text {, mitochondrial (Fragment) } \\
\text { OS=Homo sapiens GN=ATP5G1 PE=3 SV=1 - [I3L0Y5_HUMAN] }\end{array}$ & 98 & 10.0322 & 1.5333557 & $p<0.05$ \\
\hline K7EKD8 & $\begin{array}{l}\text { Calpain small subunit } 1 \text { OS=Homo sapiens GN=CAPNS1 PE=1 } \\
\text { SV=1 - [K7EKD8_HUMAN] }\end{array}$ & 238 & 24.786 & 1.5273755 & $p<0.001$ \\
\hline P25815 & $\begin{array}{l}\text { Protein S100-P OS=Homo sapiens GN=S100P PE }=1 \\
\text { SV=2 - [S100P_HUMAN] }\end{array}$ & 95 & 10.3932 & 1.4987172 & $p<0.01$ \\
\hline E9PB18 & $\begin{array}{l}\text { UPF0577 protein KIAA1324 (Fragment) OS=Homo sapiens } \\
\text { GN=KIAA1324 PE=4 SV=1 - [E9PB18_HUMAN] }\end{array}$ & 901 & 99.3015 & 1.4958927 & $p<0.001$ \\
\hline P07237 & $\begin{array}{l}\text { Protein disulfide-isomerase OS=Homo sapiens GN=P4HB } \\
\mathrm{PE}=1 \mathrm{SV}=3 \text { - [PDIA1_HUMAN] }\end{array}$ & 508 & 57.0807 & 1.4837204 & $p<0.001$ \\
\hline Q9UHB6 & $\begin{array}{l}\text { LIM domain and actin-binding protein } 1 \mathrm{OS}=\text { Homo sapiens } \\
\text { GN=LIMA1 PE }=1 \mathrm{SV}=1 \text { - [LIMA1_HUMAN] }\end{array}$ & 759 & 85.1734 & 1.4787853 & $p<0.001$ \\
\hline P18463 & $\begin{array}{l}\text { HLA class I histocompatibility antigen, B-37 alpha chain } \\
\text { OS=Homo sapiens GN=HLA-B PE=1 SV=1 - [1B37_HUMAN] }\end{array}$ & 362 & 40.4311 & 1.4620279 & $p<0.001$ \\
\hline A0A087WT15 & $\begin{array}{l}\text { Putative bifunctional UDP-N-acetylglucosamine transferase } \\
\text { and deubiquitinase ALG13 OS=Homo sapiens GN=ALG13 } \\
\mathrm{PE}=4 \mathrm{SV}=1-\text { [A0A087WT15_HUMAN] }\end{array}$ & 61 & 6.87346 & 1.4589875 & $p<0.01$ \\
\hline P40121 & $\begin{array}{l}\text { Macrophage-capping protein OS=Homo sapiens GN=CAPG } \\
\mathrm{PE}=1 \mathrm{SV}=2-[\text { CAPG_HUMAN] }\end{array}$ & 348 & 38.4745 & 1.4573444 & $p<0.001$ \\
\hline Q9Y2Q3 & $\begin{array}{l}\text { Glutathione S-transferase kappa } 1 \text { OS=Homo sapiens GN=GSTK1 } \\
\mathrm{PE}=1 \mathrm{SV}=3-\text { [GSTK1_HUMAN] }\end{array}$ & 226 & 25.4803 & 1.4570236 & $p<0.001$ \\
\hline P04062 & $\begin{array}{l}\text { Glucosylceramidase OS=Homo sapiens GN=GBA PE }=1 \\
\text { SV=3 - [GLCM_HUMAN] }\end{array}$ & 536 & 59.6782 & 1.4367309 & $p<0.001$ \\
\hline Q9UBM7 & $\begin{array}{l}\text { 7-dehydrocholesterol reductase OS=Homo sapiens GN=DHCR7 } \\
\mathrm{PE}=1 \mathrm{SV}=1-\left[\mathrm{DHCR} 7 \_H U M A N\right]\end{array}$ & 475 & 54.4538 & 1.4332229 & $p<0.001$ \\
\hline Q9Y6N5 & $\begin{array}{l}\text { Sulfide:quinone oxidoreductase, mitochondrial OS=Homo sapiens } \\
\text { GN=SQRDL PE }=1 \mathrm{SV}=1-\left[\mathrm{SQRD} \_ \text {HUMAN] }\right.\end{array}$ & 450 & 49.9289 & 1.4319068 & $p<0.001$ \\
\hline P00367 & $\begin{array}{l}\text { Glutamate dehydrogenase 1, mitochondrial OS=Homo sapiens } \\
\text { GN=GLUD1 PE=1 SV=2 - [DHE3_HUMAN] }\end{array}$ & 558 & 61.3592 & 1.4305508 & $p<0.001$ \\
\hline O95716 & $\begin{array}{l}\text { Ras-related protein Rab-3D OS=Homo sapiens } \mathrm{GN}=\mathrm{RAB} 3 \mathrm{D} \\
\mathrm{PE}=1 \mathrm{SV}=1-\text { [RAB3D_HUMAN] }\end{array}$ & 219 & 24.2518 & 1.4262913 & $p<0.001$ \\
\hline Q24JP5 & $\begin{array}{l}\text { Transmembrane protein 132A OS=Homo sapiens GN=TMEM132A } \\
\mathrm{PE}=2 \mathrm{SV}=1-\text { [T132A_HUMAN] }\end{array}$ & 1,023 & 110.041 & 1.4186958 & $p<0.001$ \\
\hline D6RA82 & $\begin{array}{l}\text { Annexin OS=Homo sapiens GN=ANXA3 PE=1 } \\
\text { SV=1 - [D6RA82_HUMAN] }\end{array}$ & 284 & 32.0985 & 1.4022738 & $p<0.001$ \\
\hline
\end{tabular}


Table I. Continued

\begin{tabular}{|c|c|c|c|c|c|}
\hline Accession & Description & \# AAs & MW [kDa] & Fold change & $\begin{array}{c}t \text {-test } \\
(p \text {-Value })\end{array}$ \\
\hline P53007 & $\begin{array}{l}\text { Tricarboxylate transport protein, mitochondrial OS=Homo sapiens } \\
\text { GN=SLC25A1 PE=1 SV=2 - }[\text { TXTP_HUMAN }]\end{array}$ & 311 & 33.991 & 1.3987563 & $p<0.001$ \\
\hline Q8TE77 & $\begin{array}{l}\text { Protein phosphatase Slingshot homolog } 3 \text { OS=Homo sapiens } \\
\text { GN=SSH3 PE }=1 \text { SV=2 }-[\text { SSH3_HUMAN] }\end{array}$ & 659 & 72.9505 & 1.3976351 & $p<0.001$ \\
\hline Q10589 & $\begin{array}{l}\text { Bone marrow stromal antigen } 2 \text { OS=Homo sapiens GN=BST2 } \\
\mathrm{PE}=1 \mathrm{SV}=1-[\mathrm{BST} 2 \text { HUMAN] }\end{array}$ & 180 & 19.7563 & 1.3894274 & $p<0.001$ \\
\hline F8VV56 & $\begin{array}{l}\text { CD63 antigen OS=Homo sapiens GN=CD63 PE }=1 \\
\text { SV=1 - [F8VV56_HUMAN] }\end{array}$ & 145 & 16.0099 & 1.3848263 & $p<0.05$ \\
\hline Q14165 & $\begin{array}{l}\text { Malectin OS=Homo sapiens GN=MLEC } P E=1 \\
\text { SV=1 - [MLEC_HUMAN] }\end{array}$ & 292 & 32.2136 & 1.3751279 & $p<0.001$ \\
\hline A3KMH1 & $\begin{array}{l}\text { von Willebrand factor A domain-containing protein } 8 \\
\text { OS=Homo sapiens } G N=V W A 8 \mathrm{PE}=1 \mathrm{SV}=2-[\text { VWA } 8 \text { HUMAN] }\end{array}$ & 1,905 & 214.689 & 1.3749854 & $p<0.01$ \\
\hline P10606 & $\begin{array}{l}\text { Cytochrome c oxidase subunit 5B, mitochondrial } \\
\text { OS=Homo sapiens } \mathrm{GN}=\mathrm{COX} 5 \mathrm{~B} \mathrm{PE}=1 \mathrm{SV}=2-\left[\mathrm{COX} 5 \mathrm{~B} \_ \text {HUMAN] }\right.\end{array}$ & 129 & 13.6869 & 1.3698091 & $p<0.01$ \\
\hline A0A087WVJ0 & $\begin{array}{l}\text { Mucin-1 (Fragment) OS=Homo sapiens GN=MUC1 } \\
\mathrm{PE}=4 \mathrm{SV}=1-[\mathrm{A0A087WVJ0} \text { HUMAN] }\end{array}$ & 228 & 25.5498 & 1.3697826 & $p<0.001$ \\
\hline Q9Y3Q3 & $\begin{array}{l}\text { Transmembrane emp24 domain-containing protein } 3 \\
\text { OS=Homo sapiens GN=TMED3 } \mathrm{PE}=1 \mathrm{SV}=1-[\mathrm{TMED} 3 \text { HUMAN] }\end{array}$ & 217 & 24.7613 & 1.3645039 & $p<0.01$ \\
\hline P07686 & $\begin{array}{l}\text { Beta-hexosaminidase subunit beta OS=Homo sapiens GN=HEXB } \\
\mathrm{PE}=1 \mathrm{SV}=3-[\text { HEXB_HUMAN] }\end{array}$ & 556 & 63.0712 & 1.3635416 & $p<0.001$ \\
\hline O95816 & $\begin{array}{l}\text { BAG family molecular chaperone regulator } 2 \mathrm{OS}=\text { Homo sapiens } \\
\text { GN=BAG2 } \mathrm{PE}=1 \mathrm{SV}=1-\text { [BAG2_HUMAN] }\end{array}$ & 211 & 23.7572 & 1.3633407 & $p<0.01$ \\
\hline P09525 & $\begin{array}{l}\text { Annexin A4 OS=Homo sapiens GN=ANXA4 PE=1 } \\
\text { SV=4 - [ANXA4_HUMAN] }\end{array}$ & 319 & 35.8601 & 1.3605119 & $p<0.001$ \\
\hline Q9Y394 & $\begin{array}{l}\text { Dehydrogenase/reductase SDR family member } 7 \\
\text { OS=Homo sapiens GN=DHRS7 PE=1 SV=1 - [DHRS7_HUMAN] }\end{array}$ & 339 & 38.2741 & 1.3556808 & $p<0.001$ \\
\hline P58107 & $\begin{array}{l}\text { Epiplakin OS=Homo sapiens GN=EPPK1 PE=1 } \\
\text { SV=2 - [EPIPL_HUMAN] }\end{array}$ & 5,090 & 555.279 & 1.3520266 & $p<0.001$ \\
\hline P00491 & $\begin{array}{l}\text { Purine nucleoside phosphorylase OS=Homo sapiens GN=PNP } \\
\mathrm{PE}=1 \mathrm{SV}=2 \text { - [PNPH_HUMAN] }\end{array}$ & 289 & 32.0972 & 1.3504636 & $p<0.001$ \\
\hline O00625 & Pirin OS=Homo sapiens GN=PIR PE=1 SV=1 - [PIR_HUMAN] & 290 & 32.0933 & 1.3476629 & $p<0.01$ \\
\hline Q9BVC6 & $\begin{array}{l}\text { Transmembrane protein } 109 \text { OS=Homo sapiens GN=TMEM109 } \\
\mathrm{PE}=1 \mathrm{SV}=1 \text { - [TM109_HUMAN] }\end{array}$ & 243 & 26.1936 & 1.343218 & $p<0.001$ \\
\hline Q9NR28 & $\begin{array}{l}\text { Diablo homolog, mitochondrial OS=Homo sapiens } \\
\text { GN=DIABLO PE }=1 \mathrm{SV}=1-\left[\mathrm{DBLOH} \_ \text {HUMAN }\right]\end{array}$ & 239 & 27.1137 & 1.3408889 & $p<0.01$ \\
\hline Q86UP2 & $\begin{array}{l}\text { Kinectin OS=Homo sapiens GN=KTN1 PE=1 } \\
\text { SV=1 - [KTN1_HUMAN] }\end{array}$ & 1,357 & 156.179 & 1.3392072 & $p<0.001$ \\
\hline P04181 & $\begin{array}{l}\text { Ornithine aminotransferase, mitochondrial OS=Homo sapiens } \\
\text { GN=OAT PE }=1 \mathrm{SV}=1-\text { [OAT_HUMAN] }\end{array}$ & 439 & 48.5042 & 1.3330075 & $p<0.001$ \\
\hline $\mathrm{O} 15270$ & $\begin{array}{l}\text { Serine palmitoyltransferase } 2 \text { OS=Homo sapiens GN=SPTLC2 } \\
\mathrm{PE}=1 \mathrm{SV}=1-\text { [SPTC2_HUMAN] }\end{array}$ & 562 & 62.8839 & 1.3326487 & $p<0.05$ \\
\hline E9PF16 & $\begin{array}{l}\text { Acyl-CoA synthetase family member 2, mitochondrial } \\
\text { OS=Homo sapiens GN=ACSF2 PE=4 SV=1 - [E9PF16_HUMAN] }\end{array}$ & 572 & 63.6114 & 1.3315351 & $p<0.01$ \\
\hline Q14956 & $\begin{array}{l}\text { Transmembrane glycoprotein NMB OS=Homo sapiens } \\
\text { GN=GPNMB PE }=1 \mathrm{SV}=2-[\text { GPNMB_HUMAN] }\end{array}$ & 572 & 63.8819 & 1.3315248 & $p<0.01$ \\
\hline O75531 & $\begin{array}{l}\text { Barrier-to-autointegration factor OS=Homo sapiens GN=BANF1 } \\
\mathrm{PE}=1 \mathrm{SV}=1 \text { - [BAF_HUMAN] }\end{array}$ & 89 & 10.052 & 1.3302003 & $p<0.01$ \\
\hline Q9H0U4 & $\begin{array}{l}\text { Ras-related protein Rab-1B OS=Homo sapiens } \mathrm{GN}=\mathrm{RAB} 1 \mathrm{~B} \\
\mathrm{PE}=1 \mathrm{SV}=1-\left[\mathrm{RAB} 1 \mathrm{~B} \_\mathrm{HUMAN}\right]\end{array}$ & 201 & 22.1572 & 1.3258098 & $p<0.001$ \\
\hline P05783 & $\begin{array}{l}\text { Keratin, type I cytoskeletal } 18 \text { OS=Homo sapiens GN=KRT18 } \\
\mathrm{PE}=1 \mathrm{SV}=2-\left[\mathrm{K} 1 \mathrm{C} 18 \_ \text {HUMAN] }\right.\end{array}$ & 430 & 48.0285 & 1.3239039 & $p<0.001$ \\
\hline Q9UDW1 & $\begin{array}{l}\text { Cytochrome b-c1 complex subunit } 9 \text { OS=Homo sapiens } \\
\text { GN=UQCR10 PE=1 SV=3 - [QCR9_HUMAN] }\end{array}$ & 63 & 7.30383 & 1.3232184 & $p<0.001$ \\
\hline Н3ВМ67 & $\begin{array}{l}\text { Nucleolar protein } 3 \text { (Fragment) OS=Homo sapiens GN=NOL3 } \\
P E=4 \mathrm{SV}=3-[\mathrm{H} 3 \mathrm{BM} 67 \text { HUMAN] }\end{array}$ & 139 & 15.0125 & 1.3207562 & $p<0.01$ \\
\hline P50454 & $\begin{array}{l}\text { Serpin H1 OS=Homo sapiens GN=SERPINH1 PE=1 } \\
\text { SV=2 - [SERPH_HUMAN] }\end{array}$ & 418 & 46.4112 & 1.3189995 & $p<0.001$ \\
\hline P15529 & $\begin{array}{l}\text { Membrane cofactor protein OS=Homo sapiens } \mathrm{GN}=\mathrm{CD} 46 \\
\mathrm{PE}=1 \mathrm{SV}=3-\left[\mathrm{MCP} \_ \text {HUMAN] }\right.\end{array}$ & 392 & 43.7187 & 1.3184128 & $p<0.01$ \\
\hline
\end{tabular}


Table I. Continued

\begin{tabular}{|c|c|c|c|c|c|}
\hline Accession & Description & \# AAs & MW [kDa] & Fold change & $\begin{array}{c}t \text {-test } \\
(p \text {-Value })\end{array}$ \\
\hline J3KT68 & $\begin{array}{l}\text { Transmembrane protein } 97 \text { OS=Homo sapiens GN=TMEM } 97 \\
\mathrm{PE}=1 \mathrm{SV}=1-\left[\mathrm{J} 3 \mathrm{KT} 68 \_ \text {HUMAN] }\right.\end{array}$ & 92 & 10.9688 & 1.3162762 & $p<0.01$ \\
\hline P35232 & $\begin{array}{l}\text { Prohibitin OS=Homo sapiens GN=PHB PE }=1 \\
\mathrm{SV}=1-\left[\mathrm{PHB} \_ \text {HUMAN] }\right.\end{array}$ & 272 & 29.7859 & 1.3155472 & $p<0.001$ \\
\hline P29373 & $\begin{array}{l}\text { Cellular retinoic acid-binding protein } 2 \text { OS=Homo sapiens } \\
\text { GN=CRABP2 } \mathrm{PE}=1 \mathrm{SV}=2-[\mathrm{RABP} 2 \text { HUMAN }]\end{array}$ & 138 & 15.683 & 1.3147 & $p<0.001$ \\
\hline Q9BR76 & $\begin{array}{l}\text { Coronin-1B OS=Homo sapiens GN=CORO1B } \\
\mathrm{PE}=1 \mathrm{SV}=1-\left[\mathrm{COR} 1 \mathrm{~B} \_ \text {HUMAN }\right]\end{array}$ & 489 & 54.2003 & 1.3079348 & $p<0.001$ \\
\hline P61604 & $\begin{array}{l}10 \mathrm{kDa} \text { heat shock protein, mitochondrial OS=Homo sapiens } \\
\mathrm{GN}=\mathrm{HSPE} 1 \mathrm{PE}=1 \mathrm{SV}=2-\left[\mathrm{CH} 10 \_ \text {HUMAN] }\right.\end{array}$ & 102 & 10.9249 & 1.3066874 & $p<0.01$ \\
\hline P14314 & $\begin{array}{l}\text { Glucosidase } 2 \text { subunit beta OS=Homo sapiens GN=PRKCSH } \\
\mathrm{PE}=1 \mathrm{SV}=2-\text { [GLU2B_HUMAN] }\end{array}$ & 528 & 59.3878 & 1.3050784 & $p<0.001$ \\
\hline H0YDJ4 & $\begin{array}{l}\text { Ninein (Fragment) OS=Homo sapiens GN=NIN PE=1 } \\
\text { SV=1 - [H0YDJ4_HUMAN] }\end{array}$ & 1,537 & 179.439 & 1.3034976 & $p<0.01$ \\
\hline E7ERY9 & $\begin{array}{l}\text { Calcium-transporting ATPase OS=Homo sapiens GN=ATP2B1 } \\
\mathrm{PE}=1 \mathrm{SV}=2-[\text { E7ERY9_HUMAN] }\end{array}$ & 963 & 106.789 & 1.30286 & $p<0.001$ \\
\hline P26885 & $\begin{array}{l}\text { Peptidyl-prolyl cis-trans isomerase FKBP2 OS=Homo sapiens } \\
\text { GN=FKBP2 PE=1 SV=2 - [FKBP2_HUMAN] }\end{array}$ & 142 & 15.6393 & 1.3022129 & $p<0.001$ \\
\hline Q9BTV4 & $\begin{array}{l}\text { Transmembrane protein } 43 \text { OS=Homo sapiens GN=TMEM43 } \\
\mathrm{PE}=1 \mathrm{SV}=1-[\mathrm{TMM} 43 \text { HUMAN] }\end{array}$ & 400 & 44.8472 & 1.3012834 & $p<0.001$ \\
\hline Q15075 & $\begin{array}{l}\text { Early endosome antigen } 1 \mathrm{OS}=\text { Homo sapiens GN=EEA1 } \\
\mathrm{PE}=1 \mathrm{SV}=2 \text { - [EEA1_HUMAN] }\end{array}$ & 1,411 & 162.367 & 1.2999296 & $p<0.001$ \\
\hline P04004 & $\begin{array}{l}\text { Vitronectin OS=Homo sapiens } \mathrm{GN}=\mathrm{VTN} \mathrm{PE}=1 \\
\mathrm{SV}=1 \text { - [VTNC_HUMAN] }\end{array}$ & 478 & 54.2712 & 1.2952339 & $p<0.001$ \\
\hline Q6P996 & $\begin{array}{l}\text { Pyridoxal-dependent decarboxylase domain-containing protein } 1 \\
\text { OS=Homo sapiens GN=PDXDC1 PE=1 SV=2 - [PDXD1_HUMAN] }\end{array}$ & 788 & 86.6523 & 1.2938765 & $p<0.05$ \\
\hline P04179 & $\begin{array}{l}\text { Superoxide dismutase }[\mathrm{Mn}] \text {, mitochondrial OS=Homo sapiens } \\
\mathrm{GN}=\mathrm{SOD} 2 \mathrm{PE}=1 \mathrm{SV}=2-\left[\mathrm{SODM} \_ \text {HUMAN] }\right.\end{array}$ & 222 & 24.7066 & 1.293093 & $p<0.001$ \\
\hline M0QYZ0 & $\begin{array}{l}\text { Heterogeneous nuclear ribonucleoprotein U-like protein } 1 \\
\text { (Fragment) OS=Homo sapiens GN=HNRNPUL1 PE=1 } \\
\text { SV=1 - [MOQYZ0_HUMAN] }\end{array}$ & 371 & 42.2697 & 1.2927079 & $p<0.001$ \\
\hline Q9BZQ8 & $\begin{array}{l}\text { Protein Niban OS=Homo sapiens GN=FAM129A PE }=1 \\
\text { SV=1 - [NIBAN_HUMAN] }\end{array}$ & 928 & 103.07 & 1.2916002 & $p<0.001$ \\
\hline P00390 & $\begin{array}{l}\text { Glutathione reductase, mitochondrial OS=Homo sapiens } \\
\mathrm{GN}=\mathrm{GSR} \mathrm{PE}=1 \mathrm{SV}=2-\text { [GSHR_HUMAN] }\end{array}$ & 522 & 56.221 & 1.290853 & $p<0.001$ \\
\hline K7EM09 & $\begin{array}{l}\text { Transmembrane protein } 205 \text { (Fragment) OS=Homo sapiens } \\
\text { GN=TMEM205 PE=1 SV=1 - [K7EM09_HUMAN] }\end{array}$ & 120 & 13.3807 & 1.2885968 & $p<0.001$ \\
\hline I3L3E4 & $\begin{array}{l}\text { Charged multivesicular body protein } 6 \text { (Fragment) } \\
\text { OS=Homo sapiens } \mathrm{GN}=\mathrm{CHMP} 6 \mathrm{PE}=1 \mathrm{SV}=1-[\mathrm{I} \mathrm{L} 3 \mathrm{E} 4 \text { _HUMAN] }\end{array}$ & 113 & 12.9314 & 1.2840595 & $p<0.05$ \\
\hline Q9BX68 & $\begin{array}{l}\text { Histidine triad nucleotide-binding protein 2, mitochondrial } \\
\text { OS=Homo sapiens } \mathrm{GN}=\mathrm{HINT} 2 \mathrm{PE}=1 \mathrm{SV}=1-[\mathrm{HINT} 2 \text { HUMAN] }\end{array}$ & 163 & 17.1512 & 1.2837525 & $p<0.001$ \\
\hline P45973 & $\begin{array}{l}\text { Chromobox protein homolog } 5 \text { OS=Homo sapiens } \mathrm{GN}=\mathrm{CBX} 5 \\
\mathrm{PE}=1 \mathrm{SV}=1-[\mathrm{CBX} 5 \text { _HUMAN] }\end{array}$ & 191 & 22.2111 & 1.281572 & $p<0.001$ \\
\hline P05787 & $\begin{array}{l}\text { Keratin, type II cytoskeletal } 8 \text { OS=Homo sapiens GN=KRT8 } \\
\mathrm{PE}=1 \mathrm{SV}=7-\left[\mathrm{K} 2 \mathrm{C} 8 \_ \text {HUMAN }\right]\end{array}$ & 483 & 53.6711 & 1.2780591 & $p<0.001$ \\
\hline H0Y339 & $\begin{array}{l}\text { E3 ubiquitin-protein ligase RFWD2 (Fragment) OS=Homo sapiens } \\
\text { GN=RFWD2 PE=4 SV=1 - [H0Y339_HUMAN] }\end{array}$ & 566 & 64.4877 & 1.2775849 & $p<0.01$ \\
\hline P02787 & $\begin{array}{l}\text { Serotransferrin OS=Homo sapiens } \mathrm{GN}=\mathrm{TF} \mathrm{PE}=1 \\
\mathrm{SV}=3-\left[\mathrm{TRFE} \_ \text {HUMAN] }\right.\end{array}$ & 698 & 77.0136 & 1.2759193 & $p<0.01$ \\
\hline A8MT65 & $\begin{array}{l}\text { Zinc finger protein } 891 \text { OS=Homo sapiens } \mathrm{GN}=\mathrm{ZNF} 891 \\
\mathrm{PE}=2 \mathrm{SV}=2-\left[\mathrm{ZN} 891 \_ \text {HUMAN] }\right.\end{array}$ & 544 & 63.5502 & 1.2734141 & $p<0.01$ \\
\hline O75874 & $\begin{array}{l}\text { Isocitrate dehydrogenase [NADP] cytoplasmic OS=Homo sapiens } \\
\text { GN=IDH1 PE=1 SV=2 - [IDHC_HUMAN] }\end{array}$ & 414 & 46.6295 & 1.2724354 & $p<0.001$ \\
\hline P12236 & $\begin{array}{l}\mathrm{ADP} / \mathrm{ATP} \text { translocase } 3 \mathrm{OS}=\text { Homo sapiens } \mathrm{GN}=\mathrm{SLC} 25 \mathrm{~A} 6 \\
\mathrm{PE}=1 \mathrm{SV}=4-\left[\mathrm{ADT} 3 \_\mathrm{HUMAN}\right]\end{array}$ & 298 & 32.8452 & 1.2713881 & $p<0.01$ \\
\hline O75131 & $\begin{array}{l}\text { Copine-3 OS=Homo sapiens GN=CPNE3 PE }=1 \\
\text { SV=1 - [CPNE3_HUMAN] }\end{array}$ & 537 & 60.0921 & 1.2713204 & $<0.001$ \\
\hline F8VVM2 & $\begin{array}{l}\text { Phosphate carrier protein, mitochondrial OS=Homo sapiens } \\
\text { GN=SLC25A3 PE=1 SV=1 - [F8VVM2_HUMAN] }\end{array}$ & 324 & 36.1376 & 1.2702845 & $p<0.001$ \\
\hline
\end{tabular}


Table I. Continued

\begin{tabular}{|c|c|c|c|c|c|}
\hline Accession & Description & \# AAs & MW [kDa] & Fold change & $\begin{array}{c}t \text {-test } \\
(p \text {-Value })\end{array}$ \\
\hline Q2TAY7 & $\begin{array}{l}\text { WD40 repeat-containing protein SMU1 OS=Homo sapiens } \\
\text { GN=SMU1 PE=1 SV=2 - [SMU1_HUMAN] }\end{array}$ & 513 & 57.5072 & 1.2690306 & $p<0.001$ \\
\hline Q15293 & $\begin{array}{l}\text { Reticulocalbin-1 OS=Homo sapiens GN=RCN1 PE=1 } \\
\text { SV=1 - [RCN1_HUMAN] }\end{array}$ & 331 & 38.8662 & 1.2635162 & $p<0.001$ \\
\hline E9PM95 & $\begin{array}{l}\text { Apolipoprotein L2 (Fragment) OS=Homo sapiens GN=APOL2 } \\
\mathrm{PE}=1 \mathrm{SV}=1 \text { - [E9PM95_HUMAN] }\end{array}$ & 128 & 14.9386 & 1.2630585 & $p<0.01$ \\
\hline A0A087X208 & $\begin{array}{l}\text { Agrin OS=Homo sapiens GN=AGRN PE }=4 \\
\mathrm{SV}=1-\left[\mathrm{A} 0 \mathrm{~A} 087 \mathrm{X} 208 \_H U M A N\right]\end{array}$ & 1,930 & 202.162 & 1.2620734 & $p<0.001$ \\
\hline A0A087WY61 & $\begin{array}{l}\text { Nuclear mitotic apparatus protein } 1 \text { OS=Homo sapiens } \\
\text { GN=NUMA1 PE=1 SV=1 - [A0A087WY61_HUMAN] }\end{array}$ & 2,099 & 236.019 & 1.2614504 & $p<0.001$ \\
\hline Q16698 & $\begin{array}{l}\text { 2,4-dienoyl-CoA reductase, mitochondrial OS=Homo sapiens } \\
\text { GN=DECR1 PE }=1 \mathrm{SV}=1-\left[\mathrm{DECR} \_ \text {HUMAN }\right]\end{array}$ & 335 & 36.0448 & 1.2589002 & $p<0.001$ \\
\hline Q14011 & $\begin{array}{l}\text { Cold-inducible RNA-binding protein OS=Homo sapiens } \\
\text { GN=CIRBP PE }=1 \mathrm{SV}=1 \text { - [CIRBP_HUMAN] }\end{array}$ & 172 & 18.6367 & 1.2565207 & $p<0.001$ \\
\hline P14625 & $\begin{array}{l}\text { Endoplasmin OS=Homo sapiens GN=HSP90B1 PE }=1 \\
\text { SV=1 - [ENPL_HUMAN] }\end{array}$ & 803 & 92.4113 & 1.2542374 & $p<0.001$ \\
\hline Q96HE7 & $\begin{array}{l}\text { ERO1-like protein alpha OS=Homo sapiens GN=ERO1L } \\
\mathrm{PE}=1 \mathrm{SV}=2-[\text { ERO1A_HUMAN] }\end{array}$ & 468 & 54.3581 & 1.2516932 & $p<0.001$ \\
\hline P17900 & $\begin{array}{l}\text { Ganglioside GM2 activator OS=Homo sapiens GN=GM2A } \\
\mathrm{PE}=1 \mathrm{SV}=4-\left[\mathrm{SAP} 3 \_ \text {HUMAN }\right]\end{array}$ & 193 & 20.8247 & 1.2515007 & $p<0.001$ \\
\hline P27824 & $\begin{array}{l}\text { Calnexin OS=Homo sapiens GN=CANX PE }=1 \\
\text { SV=2 - [CALX_HUMAN] }\end{array}$ & 592 & 67.5259 & 1.2502035 & $p<0.001$ \\
\hline
\end{tabular}

there was a 1.47 -fold $(p<0.0001)$ reduction in the proliferation of the T47DaromLR cells (Figure 4). As the growth of the T47DaromLR cells was selectively decreased by the p38 inhibitor, we chose to assess whether this effect was associated with alterations in apoptosis. The caspase 3/7 assay was performed on both cell lines in the presence and absence of the p38 inhibitor (Figure 5). While the T47Darom cells were unresponsive, there was a slight induction in apoptosis in the T47DaromLR cells treated with the p38 inhibitor, suggesting the p38/MAPK pathway may play a role in endocrine resistance.

\section{Discussion}

Aromatase inhibitors have been the first-line agents for postmenopausal women with hormone receptor positive metastatic breast cancer for many years. However, like many agents, some women develop resistance and stop responding to therapies, which can result in tumor relapse, metastasis, and a more aggressive phenotype. Thus, understanding mechanisms of resistance are critical to the development of novel strategies to address these patients. Previous reports by our group have identified a signature of letrozole resistance that was associated with estrogen independence, increased EGFR and HER2, enhanced motility, and an EMT phenotype (2). We focused on understanding the mechanisms of AI resistance associated with hormone refractory tumors, however the distinctions between AI-resistance in the hormone dependent versus hormone independent settings remain unclear.

Here, we utilized a non-migratory, ER+ letrozole resistant cell line (i.e., derived from the T47D epithelial cells) as a model system to initially characterize changes that occur as cells transition to an acquired AI-resistant phenotype. Although these cells are ER+, they are cross resistant to the selective estrogen receptor modulator tamoxifen, (3) further demonstrating their aggressive nature and limited therapeutic options. As the AI-sensitive cells transitioned to AIresistance, both HER2 and MAPK expression were induced (6). This was a similar phenomenon previously observed in the hormone-independent AI-resistant LTLT-Ca cells (2). When the protein expression of a panel of phosphorylated receptor tyrosine kinases were evaluated, pErbB2 (i.e., pHER2) expression was decreased in the T47DaromLR cells compared to the T47DaromLR cells, suggesting that other pathways may be responsible for the acquired resistance. This was a unique feature of the T47DaromLR cells compared to the LTLT-Ca cells. Previous reports have demonstrated that increased pHER2 expression in the LTLT$\mathrm{Ca}$ cells and trastuzumab was capable of reversing the resistance and restoring sensitivity to letrozole (15).

Since the T47DaromLR cells exhibited increased MAPK, we evaluated a panel of phosphorylated proteins involved in the MAPK signaling cascade. Signaling components and effectors of the p38/MAPK pathway (i.e., MKK6 and p38) 
Table II. Down-regulated proteins in letrozole resistant T47DaromLR breast cancer cells. Proteomic analyses were performed as described in the Methods section and the ratio of the fold change in T47DaromLR/T47Darom cells is shown. The text in bold indicates a protein of interest.

\begin{tabular}{|c|c|c|c|c|c|}
\hline Accession & Description & \# AAs & MW [kDa] & Fold change & $\begin{array}{c}t \text {-test } \\
(p \text {-value })\end{array}$ \\
\hline Q15185 & $\begin{array}{l}\text { Prostaglandin E synthase } 3 \text { OS=Homo sapiens GN=PTGES3 } \\
\mathrm{PE}=1 \mathrm{SV}=1-\left[\mathrm{TEBP} \_ \text {HUMAN] }\right.\end{array}$ & 160 & 18.6854194 & 0.79904589 & $p<0.01$ \\
\hline Q9NYL9 & $\begin{array}{l}\text { Tropomodulin-3 OS=Homo sapiens GN=TMOD3 PE }=1 \\
\text { SV=1 - [TMOD3_HUMAN] }\end{array}$ & 352 & 39.5703018 & 0.79902558 & $p<0.05$ \\
\hline P18669 & $\begin{array}{l}\text { Phosphoglycerate mutase } 1 \text { OS=Homo sapiens GN=PGAM1 } \\
\mathrm{PE}=1 \mathrm{SV}=2-[\text { PGAM1_HUMAN] }\end{array}$ & 254 & 28.7858365 & 0.79865701 & $p<0.001$ \\
\hline P19338 & $\begin{array}{l}\text { Nucleolin OS=Homo sapiens GN=NCL PE }=1 \\
\mathrm{SV}=3-[\text { NUCL_HUMAN] }\end{array}$ & 710 & 76.5683628 & 0.79790721 & $p<0.001$ \\
\hline Q12931 & $\begin{array}{l}\text { Heat shock protein } 75 \mathrm{kDa} \text {, mitochondrial OS=Homo sapiens } \\
\text { GN=TRAP1 PE }=1 \mathrm{SV}=3-[\text { TRAP1_HUMAN] }\end{array}$ & 704 & 80.0596949 & 0.79777903 & $p<0.001$ \\
\hline Q86Y56 & $\begin{array}{l}\text { HEAT repeat-containing protein } 2 \mathrm{OS}=\text { Homo sapiens } \\
\mathrm{GN}=\mathrm{HEATR} 2 \mathrm{PE}=1 \mathrm{SV}=4-[\mathrm{HEAT} 2 \text { HUMAN] }\end{array}$ & 855 & 93.4620686 & 0.79675307 & $p<0.001$ \\
\hline K7EJE8 & $\begin{array}{l}\text { Lon protease homolog, mitochondrial OS=Homo sapiens } \\
\text { GN=LONP1 PE }=1 \mathrm{SV}=1 \text { - [K7EJE8_HUMAN] }\end{array}$ & 829 & 93.2379667 & 0.79656905 & $p<0.001$ \\
\hline Q8IZ52 & $\begin{array}{l}\text { Chondroitin sulfate synthase } 2 \text { OS=Homo sapiens } \\
\text { GN=CHPF PE }=1 \mathrm{SV}=2-\left[\mathrm{CHSS} 2 \_ \text {HUMAN }\right]\end{array}$ & 775 & 85.4140471 & 0.79611883 & $p<0.01$ \\
\hline P31939 & $\begin{array}{l}\text { Bifunctional purine biosynthesis protein PURH } \\
\text { OS=Homo sapiens GN=ATIC } \mathrm{PE}=1 \mathrm{SV}=3 \text { - [PUR9_HUMAN] }\end{array}$ & 592 & 64.5753451 & 0.79607097 & $p<0.001$ \\
\hline O15371 & $\begin{array}{l}\text { Eukaryotic translation initiation factor } 3 \text { subunit D } \\
\text { OS=Homo sapiens GN=EIF3D PE }=1 \mathrm{SV}=1-[\text { EIF3D_HUMAN] }\end{array}$ & 548 & 63.9324345 & 0.79584502 & $p<0.001$ \\
\hline P12004 & $\begin{array}{l}\text { Proliferating cell nuclear antigen OS=Homo sapiens } \mathrm{GN}=\mathrm{PCNA} \\
\mathrm{PE}=1 \mathrm{SV}=1-[\mathrm{PCNA} \text { HUMAN] }\end{array}$ & 261 & 28.7502945 & 0.79483268 & $p<0.001$ \\
\hline P68371 & $\begin{array}{l}\text { Tubulin beta-4B chain OS=Homo sapiens GN=TUBB4B } \\
\mathrm{PE}=1 \mathrm{SV}=1-\left[\mathrm{TBB} 4 \mathrm{~B} \_ \text {HUMAN] }\right.\end{array}$ & 445 & 49.7990043 & 0.79464307 & $p<0.01$ \\
\hline V9GYX7 & $\begin{array}{l}\text { Actin-related protein } 10 \text { (Fragment) OS=Homo sapiens } \\
\text { GN=ACTR10 PE=1 SV=1 - [V9GYX7_HUMAN] }\end{array}$ & 302 & 33.2901748 & 0.79372567 & $p<0.05$ \\
\hline P62258 & $\begin{array}{l}\text { 14-3-3 protein epsilon OS=Homo sapiens } \mathrm{GN}=\mathrm{YWHAE} \\
\mathrm{PE}=1 \mathrm{SV}=1-\left[1433 \mathrm{E} \_ \text {HUMAN] }\right.\end{array}$ & 255 & 29.1554174 & 0.7932199 & $p<0.001$ \\
\hline Q9NZL9 & $\begin{array}{l}\text { Methionine adenosyltransferase } 2 \text { subunit beta } O S=\text { Homo sapiens } \\
\text { GN=MAT2B PE }=1 \mathrm{SV}=1-[\text { MAT2B_HUMAN] }\end{array}$ & 334 & 37.5281776 & 0.7926943 & $p<0.001$ \\
\hline P13995 & $\begin{array}{l}\text { Bifunctional methylenetetrahydrofolate dehydrogenase/ } \\
\text { cyclohydrolase, mitochondrial OS=Homo sapiens GN=MTHFD2 } \\
\text { PE=1 SV=2 - [MTDC_HUMAN] }\end{array}$ & 350 & 37.8711975 & 0.79227913 & $p<0.01$ \\
\hline P62826 & $\begin{array}{l}\text { GTP-binding nuclear protein Ran OS=Homo sapiens GN=RAN } \\
\mathrm{PE}=1 \mathrm{SV}=3 \text { - [RAN_HUMAN] }\end{array}$ & 216 & 24.4076189 & 0.791804 & $p<0.001$ \\
\hline P50990 & $\begin{array}{l}\text { T-complex protein } 1 \text { subunit theta OS=Homo sapiens } \\
\text { GN=CCT } 8 \text { PE }=1 \mathrm{SV}=4-[\text { TCPQ_HUMAN }]\end{array}$ & 548 & 59.582509 & 0.78997166 & $p<0.001$ \\
\hline M0R210 & $\begin{array}{l}\text { 40S ribosomal protein S16 OS=Homo sapiens GN=RPS16 PE=1 } \\
\text { SV }=1-[\text { M0R210_HUMAN] }\end{array}$ & 129 & 14.4099586 & 0.78837739 & $p<0.001$ \\
\hline Q9NPH2 & $\begin{array}{l}\text { Inositol-3-phosphate synthase } 1 \text { OS=Homo sapiens GN=ISYNA1 } \\
\mathrm{PE}=1 \mathrm{SV}=1-[\mathrm{INO} \text { HUMAN] }\end{array}$ & 558 & 61.029104 & 0.78806023 & $p<0.01$ \\
\hline Q32Q12 & $\begin{array}{l}\text { Nucleoside diphosphate kinase OS=Homo sapiens } \\
\text { GN=NME1-NME2 PE=1 SV=1 - [Q32Q12_HUMAN] }\end{array}$ & 292 & 32.6208685 & 0.78792838 & $p<0.001$ \\
\hline P40937 & $\begin{array}{l}\text { Replication factor } \mathrm{C} \text { subunit } 5 \text { OS=Homo sapiens } \mathrm{GN}=\mathrm{RFC} 5 \\
\mathrm{PE}=1 \mathrm{SV}=1-[\mathrm{RFC} 5 \text { HUMAN] }\end{array}$ & 340 & 38.4721873 & 0.78511694 & $p<0.01$ \\
\hline D6RFM5 & $\begin{array}{l}\text { Succinate dehydrogenase [ubiquinone] flavoprotein subunit, } \\
\text { mitochondrial OS=Homo sapiens GN=SDHA PE }=1 \\
\text { SV=1 - [D6RFM5_HUMAN] }\end{array}$ & 583 & 63.5266889 & 0.78479348 & $p<0.001$ \\
\hline $\mathrm{H} 7 \mathrm{C} 3 \mathrm{~S} 9$ & $\begin{array}{l}\text { COP9 signalosome complex subunit } 8 \text { (Fragment) } \\
\text { OS=Homo sapiens GN=COPS } 8 \mathrm{PE}=1 \mathrm{SV}=1-\left[\mathrm{H} 7 \mathrm{C} 3 \mathrm{~S} 9 \_\mathrm{HUMAN}\right]\end{array}$ & 83 & 9.03868894 & 0.78280605 & $p<0.001$ \\
\hline Q99536 & $\begin{array}{l}\text { Synaptic vesicle membrane protein VAT-1 homolog } \\
\text { OS=Homo sapiens GN=VAT1 PE=1 SV=2 - [VAT1_HUMAN] }\end{array}$ & 393 & 41.8934194 & 0.78202386 & $p<0.001$ \\
\hline Q9BUF5 & $\begin{array}{l}\text { Tubulin beta- } 6 \text { chain OS=Homo sapiens GN=TUBB6 } \\
\mathrm{PE}=1 \mathrm{SV}=1-\left[\mathrm{TBB} 6 \_ \text {HUMAN] }\right.\end{array}$ & 446 & 49.8250022 & 0.78081583 & $p<0.05$ \\
\hline Q9Y2Z0 & $\begin{array}{l}\text { Suppressor of G2 allele of SKP1 homolog OS=Homo sapiens } \\
\text { GN=SUGT1 PE=1 SV=3 - [SUGT1_HUMAN] }\end{array}$ & 365 & 40.998492 & 0.78075718 & $p<0.05$ \\
\hline E7EUH7 & $\begin{array}{l}\text { Pseudouridylate synthase } 7 \text { homolog OS=Homo sapiens } \\
\text { GN=PUS7 PE=1 SV=1 - [E7EUH7_HUMAN] }\end{array}$ & 448 & 50.5206902 & 0.78060885 & $p<0.05$ \\
\hline
\end{tabular}


Table II. Continued

\begin{tabular}{|c|c|c|c|c|c|}
\hline Accession & Description & \# AAs & MW [kDa] & Fold change & $\begin{array}{c}t \text {-test } \\
(p \text {-value })\end{array}$ \\
\hline Q13907 & $\begin{array}{l}\text { Isopentenyl-diphosphate Delta-isomerase } 1 \mathrm{OS}=\text { Homo sapiens } \\
\text { GN=IDI1 PE }=1 \mathrm{SV}=2-[\text { IDI1_HUMAN] }\end{array}$ & 227 & 26.3024914 & 0.7785156 & $p<0.001$ \\
\hline F8VXD2 & $\begin{array}{l}\text { Cyclin-dependent kinase } 4 \text { (Fragment) OS=Homo sapiens } \\
\text { GN=CDK4 PE=1 SV=1 - [F8VXD2_HUMAN] }\end{array}$ & 132 & 14.8906691 & 0.77756677 & $p<0.05$ \\
\hline P08559 & $\begin{array}{l}\text { Pyruvate dehydrogenase E1 component subunit alpha, } \\
\text { somatic form, mitochondrial OS=Homo sapiens } \\
\text { GN=PDHA1 } \mathrm{PE}=1 \mathrm{SV}=3 \text { - [ODPA_HUMAN] }\end{array}$ & 390 & 43.2676109 & 0.77727405 & $p<0.001$ \\
\hline O00762 & $\begin{array}{l}\text { Ubiquitin-conjugating enzyme E2 C OS=Homo sapiens } \\
\text { GN=UBE2C } P E=1 S V=1-[\text { UBE2C_HUMAN] }\end{array}$ & 179 & 19.6399202 & 0.77693257 & $p<0.001$ \\
\hline P43490 & $\begin{array}{l}\text { Nicotinamide phosphoribosyltransferase OS=Homo sapiens } \\
\text { GN=NAMPT PE }=1 \mathrm{SV}=1-[\text { NAMPT_HUMAN] }\end{array}$ & 491 & 55.4865965 & 0.77652882 & $p<0.001$ \\
\hline D6RDM7 & $\begin{array}{l}\text { Ubiquitin-conjugating enzyme E2 K (Fragment) OS=Homo sapiens } \\
\text { GN=UBE2K PE }=1 \text { SV=1 - [D6RDM7_HUMAN] }\end{array}$ & 123 & 14.0261903 & 0.77622448 & $p<0.001$ \\
\hline E5RFP0 & $\begin{array}{l}\text { NudC domain-containing protein } 2 \text { OS=Homo sapiens } \\
\text { GN=NUDCD2 } \mathrm{PE}=1 \mathrm{SV}=1-\left[\mathrm{E} 5 \mathrm{RFP} 0 \_ \text {HUMAN] }\right.\end{array}$ & 132 & 14.7361652 & 0.77511218 & $p<0.01$ \\
\hline Q04917 & $\begin{array}{l}\text { 14-3-3 protein eta OS=Homo sapiens } \mathrm{GN}=\mathrm{YWHAH} \mathrm{PE}=1 \\
\mathrm{SV}=4-\left[1433 \mathrm{~F} \_ \text {HUMAN] }\right.\end{array}$ & 246 & 28.20102 & 0.77478302 & $p<0.01$ \\
\hline P29144 & $\begin{array}{l}\text { Tripeptidyl-peptidase } 2 \text { OS=Homo sapiens GN=TPP2 } \\
\mathrm{PE}=1 \mathrm{SV}=4-[\mathrm{TPP} 2 \text { HUMAN] }\end{array}$ & 1,249 & 138.262632 & 0.77415019 & $p<0.01$ \\
\hline P68032 & $\begin{array}{l}\text { Actin, alpha cardiac muscle } 1 \text { OS=Homo sapiens GN=ACTC1 } \\
P E=1 S V=1-[\text { ACTC_HUMAN] }\end{array}$ & 377 & 41.9918826 & 0.77329561 & $p<0.001$ \\
\hline Q562R1 & $\begin{array}{l}\text { Beta-actin-like protein } 2 \text { OS=Homo sapiens } \mathrm{GN}=\mathrm{ACTBL} 2 \\
\mathrm{PE}=1 \mathrm{SV}=2-\left[\mathrm{ACTBL} \_ \text {HUMAN] }\right.\end{array}$ & 376 & 41.9759693 & 0.76932533 & $p<0.001$ \\
\hline Q14914 & $\begin{array}{l}\text { Prostaglandin reductase } 1 \text { OS=Homo sapiens GN=PTGR1 } \\
\mathrm{PE}=1 \mathrm{SV}=2-\left[\mathrm{PTGR} 1 \_ \text {HUMAN] }\right.\end{array}$ & 329 & 35.8467307 & 0.76842181 & $p<0.01$ \\
\hline Q05639 & $\begin{array}{l}\text { Elongation factor 1-alpha } 2 \text { OS=Homo sapiens GN=EEF1A2 } \\
\mathrm{PE}=1 \mathrm{SV}=1-\left[\mathrm{EF} 1 \mathrm{~A} 2 \_ \text {HUMAN] }\right.\end{array}$ & 463 & 50.4383096 & 0.76649072 & $p<0.001$ \\
\hline P06396 & $\begin{array}{l}\text { Gelsolin OS=Homo sapiens GN=GSN PE=1 } \\
\mathrm{SV}=1-\text { [GELS_HUMAN] }\end{array}$ & 782 & 85.6441934 & 0.76419352 & $p<0.001$ \\
\hline P11908 & $\begin{array}{l}\text { Ribose-phosphate pyrophosphokinase } 2 \text { OS=Homo sapiens } \\
\text { GN=PRPS2 PE }=1 \text { SV=2 - [PRPS2_HUMAN] }\end{array}$ & 318 & 34.7469789 & 0.76381858 & $p<0.01$ \\
\hline Q58FF6 & $\begin{array}{l}\text { Putative heat shock protein HSP } 90-\text { beta } 4 \text { OS=Homo sapiens } \\
\text { GN=HSP90AB4P PE }=5 \mathrm{SV}=1-\left[\mathrm{H} 90 \mathrm{~B} 4 \_ \text {HUMAN }\right]\end{array}$ & 505 & 58.2275805 & 0.76277969 & $p<0.001$ \\
\hline Н7С3Р9 & $\begin{array}{l}\text { COP9 signalosome complex subunit } 3 \text { OS }=\text { Homo sapiens } \\
\text { GN=COPS3 PE }=1 \mathrm{SV}=2-[\mathrm{H} 7 \mathrm{C} 3 \mathrm{P} 9 \text { _HUMAN] }\end{array}$ & 345 & 39.0105281 & 0.76178683 & $p<0.001$ \\
\hline P80404 & $\begin{array}{l}\text { 4-aminobutyrate aminotransferase, mitochondrial } \\
\mathrm{OS}=\text { Homo sapiens } \mathrm{GN}=\mathrm{ABAT} \mathrm{PE}=1 \mathrm{SV}=3-\left[\mathrm{GABT} \_ \text {HUMAN] }\right.\end{array}$ & 500 & 56.4025903 & 0.75993164 & $p<0.001$ \\
\hline P17174 & $\begin{array}{l}\text { Aspartate aminotransferase, cytoplasmic OS=Homo sapiens } \\
\text { GN=GOT1 PE }=1 \text { SV=3 - [AATC_HUMAN] }\end{array}$ & 413 & 46.2185309 & 0.75976861 & $p<0.001$ \\
\hline Q9HB71 & $\begin{array}{l}\text { Calcyclin-binding protein OS=Homo sapiens } \mathrm{GN}=\mathrm{CACYBP} \\
\mathrm{PE}=1 \mathrm{SV}=2-\left[\mathrm{CYBP} \_\mathrm{HUMAN}\right]\end{array}$ & 228 & 26.1936459 & 0.75789333 & $p<0.001$ \\
\hline P62328 & $\begin{array}{l}\text { Thymosin beta- } 4 \text { OS=Homo sapiens GN=TMSB4X } \\
\mathrm{PE}=1 \mathrm{SV}=2-[\mathrm{TYB} 4 \text { _HUMAN] }\end{array}$ & 44 & 5.04951649 & 0.75606602 & $p<0.05$ \\
\hline E9PNK6 & $\begin{array}{l}\text { Tumor protein D53 OS=Homo sapiens GN=TPD52L1 } \\
\mathrm{PE}=1 \mathrm{SV}=1-[\text { E9PNK6_HUMAN] }\end{array}$ & 166 & 18.6492831 & 0.75524912 & $p<0.01$ \\
\hline Q96IU4 & $\begin{array}{l}\text { Alpha/beta hydrolase domain-containing protein } 14 \mathrm{~B} \\
\mathrm{OS}=\text { Homo sapiens } \mathrm{GN}=\mathrm{ABHD} 14 \mathrm{~B} \mathrm{PE}=1 \mathrm{SV}=1-\left[\mathrm{ABHEB} \_ \text {HUMAN] }\right.\end{array}$ & 210 & 22.3315574 & 0.75457008 & $p<0.01$ \\
\hline Q9NP72 & $\begin{array}{l}\text { Ras-related protein Rab-18 OS=Homo sapiens GN=RAB18 } \\
\mathrm{PE}=1 \mathrm{SV}=1-\left[\mathrm{RAB} 18 \_H U M A N\right]\end{array}$ & 206 & 22.9626389 & 0.7544287 & $p<0.001$ \\
\hline C9JLU1 & $\begin{array}{l}\text { DNA-directed RNA polymerases I, II, and III subunit } \\
\text { RPABC3 (Fragment) OS=Homo sapiens GN=POLR2H } \\
\text { PE=1 SV=3 - [C9JLU1_HUMAN] }\end{array}$ & 149 & 16.9853803 & 0.75427123 & $p<0.01$ \\
\hline Q8N0Y7 & $\begin{array}{l}\text { Probable phosphoglycerate mutase } 4 \text { OS=Homo sapiens } \\
\text { GN=PGAM4 } \mathrm{PE}=2 \mathrm{SV}=1 \text { - [PGAM4_HUMAN] }\end{array}$ & 254 & 28.7587667 & 0.75337853 & $p<0.05$ \\
\hline E9PLT0 & $\begin{array}{l}\text { Cold shock domain-containing protein E1 OS=Homo sapiens } \\
\mathrm{GN}=\mathrm{CSDE} 1 \mathrm{PE}=1 \mathrm{SV}=1 \text { - [E9PLT0_HUMAN] }\end{array}$ & 668 & 74.5367585 & 0.75176491 & $p<0.001$ \\
\hline P07900 & $\begin{array}{l}\text { Heat shock protein HSP 90-alpha OS=Homo sapiens } \\
\text { GN=HSP90AA1 PE }=1 \mathrm{SV}=5-[\text { HS90A_HUMAN] }\end{array}$ & 732 & 84.6066852 & 0.75149833 & $p<0.001$ \\
\hline
\end{tabular}


Table II. Continued

\begin{tabular}{|c|c|c|c|c|c|}
\hline Accession & Description & \# AAs & MW [kDa] & Fold change & $\begin{array}{c}t \text {-test } \\
(p \text {-value })\end{array}$ \\
\hline F5H345 & $\begin{array}{l}\text { Porphobilinogen deaminase OS=Homo sapiens GN=HMBS } \\
\mathrm{PE}=1 \mathrm{SV}=1-\left[\mathrm{F} 5 \mathrm{H} 345 \_ \text {HUMAN] }\right.\end{array}$ & 330 & 35.7388228 & 0.75086131 & $p<0.01$ \\
\hline P41227 & $\begin{array}{l}\text { N-alpha-acetyltransferase } 10 \text { OS=Homo sapiens GN=NAA10 } \\
P E=1 \quad S V=1-[\text { NAA10_HUMAN] }\end{array}$ & 235 & 26.4418527 & 0.75055952 & $p<0.001$ \\
\hline P35580 & $\begin{array}{l}\text { Myosin-10 OS=Homo sapiens GN=MYH10 PE=1 } \\
\text { SV=3 - [MYH10_HUMAN] }\end{array}$ & 1,976 & 228.857964 & 0.75001828 & $p<0.01$ \\
\hline P36507 & $\begin{array}{l}\text { Dual specificity mitogen-activated protein kinase kinase } 2 \\
\text { OS=Homo sapiens GN=MAP2K2 PE=1 SV=1 - [MP2K2_HUMAN] }\end{array}$ & 400 & 44.396055 & 0.7484181 & $p<0.01$ \\
\hline Q9UNF1 & $\begin{array}{l}\text { Melanoma-associated antigen D2 OS=Homo sapiens } \\
\text { GN=MAGED2 } \mathrm{PE}=1 \mathrm{SV}=2-[\mathrm{MAGD} 2 \text { _HUMAN] }\end{array}$ & 606 & 64.9143628 & 0.74753167 & $p<0.001$ \\
\hline P61981 & $\begin{array}{l}\text { 14-3-3 protein gamma OS=Homo sapiens } \mathrm{GN}=\mathrm{YWHAG} \\
\mathrm{PE}=1 \mathrm{SV}=2-\left[1433 \mathrm{G} \_ \text {HUMAN] }\right.\end{array}$ & 247 & 28.2849139 & 0.74714741 & $p<0.001$ \\
\hline Q9Y265 & $\begin{array}{l}\text { RuvB-like } 1 \text { OS=Homo sapiens GN=RUVBL1 PE=1 } \\
\text { SV=1 - [RUVB1_HUMAN] }\end{array}$ & 456 & 50.1963165 & 0.74346671 & $p<0.001$ \\
\hline Q7L2H7 & $\begin{array}{l}\text { Eukaryotic translation initiation factor } 3 \text { subunit } \mathrm{M} \\
\text { OS=Homo sapiens } \mathrm{GN}=\mathrm{EIF3M} \mathrm{PE}=1 \mathrm{SV}=1-\text { [EIF3M_HUMAN] }\end{array}$ & 374 & 42.475807 & 0.74293059 & $p<0.01$ \\
\hline Q9BQE3 & $\begin{array}{l}\text { Tubulin alpha-1C chain OS=Homo sapiens GN=TUBA1C } \\
P E=1 \mathrm{SV}=1-[\text { TBA1C_HUMAN] }\end{array}$ & 449 & 49.8634645 & 0.74276939 & $p<0.001$ \\
\hline P13639 & $\begin{array}{l}\text { Elongation factor } 2 \text { OS=Homo sapiens } \mathrm{GN}=\mathrm{EEF} 2 \\
\mathrm{PE}=1 \mathrm{SV}=4-\left[\mathrm{EF} 2 \_\mathrm{HUMAN}\right]\end{array}$ & 858 & 95.2769538 & 0.73926002 & $p<0.001$ \\
\hline C9JPA8 & $\begin{array}{l}\text { Golgi to ER traffic protein } 4 \text { homolog (Fragment) } \\
\text { OS=Homo sapiens } \mathrm{GN}=\mathrm{GET} 4 \mathrm{PE}=1 \mathrm{SV}=2 \text { - [C9JPA8_HUMAN] }\end{array}$ & 148 & 16.5321422 & 0.73902176 & $p<0.001$ \\
\hline Q53EL6 & $\begin{array}{l}\text { Programmed cell death protein } 4 \text { OS=Homo sapiens } \\
\text { GN=PDCD4 } \mathrm{PE}=1 \mathrm{SV}=2-[\mathrm{PDCD} 4 \text { _HUMAN] }\end{array}$ & 469 & 51.7030487 & 0.73378818 & $p<0.001$ \\
\hline E5RG13 & $\begin{array}{l}\text { Inositol monophosphatase } 1 \text { (Fragment) OS=Homo sapiens } \\
\text { GN=IMPA1 PE }=1 \mathrm{SV}=1 \text { - [E5RG13_HUMAN] }\end{array}$ & 153 & 17.0476334 & 0.73217864 & $p<0.01$ \\
\hline O96019 & $\begin{array}{l}\text { Actin-like protein 6A OS=Homo sapiens GN=ACTL6A } \\
\mathrm{PE}=1 \mathrm{SV}=1-\text { [ACL6A_HUMAN] }\end{array}$ & 429 & 47.4303444 & 0.7298752 & $p<0.01$ \\
\hline O75369 & $\begin{array}{l}\text { Filamin-B OS=Homo sapiens GN=FLNB PE }=1 \\
\text { SV=2 - [FLNB_HUMAN] }\end{array}$ & 2,602 & 277.990071 & 0.72651996 & $p<0.001$ \\
\hline P68363 & $\begin{array}{l}\text { Tubulin alpha-1B chain OS=Homo sapiens GN=TUBA1B } \\
\mathrm{PE}=1 \mathrm{SV}=1-\left[\mathrm{TBA} 1 \mathrm{~B} \_ \text {HUMAN] }\right.\end{array}$ & 451 & 50.1196069 & 0.72651105 & $p<0.001$ \\
\hline Q9H0C2 & $\begin{array}{l}\text { ADP/ATP translocase } 4 \text { OS=Homo sapiens GN=SLC25A31 } \\
\mathrm{PE}=2 \mathrm{SV}=1-[\mathrm{ADT} 4 \text { HUMAN] }\end{array}$ & 315 & 34.9994373 & 0.72226342 & $p<0.01$ \\
\hline Q8TC12 & $\begin{array}{l}\text { Retinol dehydrogenase } 11 \text { OS=Homo sapiens GN=RDH11 } \\
\mathrm{PE}=1 \mathrm{SV}=2-\left[\mathrm{RDH} 11 \_ \text {HUMAN] }\right.\end{array}$ & 318 & 35.3634467 & 0.72142867 & $p<0.001$ \\
\hline P08238 & $\begin{array}{l}\text { Heat shock protein HSP 90-beta OS=Homo sapiens } \\
\text { GN=HSP90AB1 PE=1 SV=4 - [HS90B_HUMAN] }\end{array}$ & 724 & 83.2121059 & 0.71815962 & $p<0.001$ \\
\hline P11177 & $\begin{array}{l}\text { Pyruvate dehydrogenase E1 component subunit beta, mitochondrial } \\
\mathrm{OS}=\text { Homo sapiens } \mathrm{GN}=\mathrm{PDHB} \mathrm{PE}=1 \mathrm{SV}=3 \text { - [ODPB_HUMAN] }\end{array}$ & 359 & 39.2080346 & 0.71532722 & $p<0.001$ \\
\hline A0A087WWP8 & $\begin{array}{l}\text { Round spermatid basic protein } 1 \text { OS=Homo sapiens GN=RSBN1 } \\
\mathrm{PE}=1 \mathrm{SV}=1-[\mathrm{A} 0 \mathrm{~A} 087 \mathrm{WWP} 8 \text { HUMAN] }\end{array}$ & 754 & 84.922968 & 0.70870038 & $p<0.05$ \\
\hline P00338 & $\begin{array}{l}\text { L-lactate dehydrogenase A chain OS=Homo sapiens GN=LDHA } \\
P E=1 S V=2-[\text { LDHA_HUMAN] }\end{array}$ & 332 & 36.6653627 & 0.70859232 & $p<0.001$ \\
\hline Q96CP2 & $\begin{array}{l}\text { FLYWCH family member } 2 \text { OS=Homo sapiens GN=FLYWCH2 } \\
\mathrm{PE}=1 \mathrm{SV}=1-[\mathrm{FWCH} 2 \text { HUMAN] }\end{array}$ & 140 & 14.5545451 & 0.7042261 & $p<0.05$ \\
\hline $\mathrm{O} 00232$ & $\begin{array}{l}\text { 26S proteasome non-ATPase regulatory subunit } 12 \\
\mathrm{OS}=\text { Homo sapiens } \mathrm{GN}=\mathrm{PSMD} 12 \mathrm{PE}=1 \mathrm{SV}=3-\text { [PSD12_HUMAN] }\end{array}$ & 456 & 52.8705755 & 0.70028253 & $p<0.001$ \\
\hline P07437 & $\begin{array}{l}\text { Tubulin beta chain } \mathrm{OS}=\text { Homo sapiens } \mathrm{GN}=\mathrm{TUBB} \mathrm{PE}=1 \\
\mathrm{SV}=2-[\mathrm{TBB} 5 \text { _HUMAN] }\end{array}$ & 444 & 49.6389736 & 0.69867551 & $p<0.001$ \\
\hline Q9HAV0 & $\begin{array}{l}\text { Guanine nucleotide-binding protein subunit beta- } 4 \\
\mathrm{OS}=\text { Homo sapiens } \mathrm{GN}=\mathrm{GNB} 4 \mathrm{PE}=1 \mathrm{SV}=3-[\mathrm{GBB} 4 \text { HUMAN] }\end{array}$ & 340 & 37.5430236 & 0.69638699 & $p<0.001$ \\
\hline P62937 & $\begin{array}{l}\text { Peptidyl-prolyl cis-trans isomerase A OS=Homo sapiens } \\
\text { GN=PPIA PE }=1 \mathrm{SV}=2 \text { - [PPIA_HUMAN] }\end{array}$ & 165 & 18.0008862 & 0.69099459 & $p<0.001$ \\
\hline P41250 & $\begin{array}{l}\text { Glycine--tRNA ligase OS=Homo sapiens GN=GARS } \\
\mathrm{PE}=1 \mathrm{SV}=3-\left[\mathrm{SYG}_{-} \text {HUMAN }\right]\end{array}$ & 739 & 83.1126144 & 0.68820486 & $p<0.001$ \\
\hline A0A087WW67 & $\begin{array}{l}\text { Inactive } \mathrm{N} \text {-acetylated-alpha-linked acidic dipeptidase-like } \\
\text { protein } 2 \text { OS=Homo sapiens GN=NAALADL2 PE }=4 \\
\text { SV=1 - [A0A087WW67_HUMAN] }\end{array}$ & 783 & 87.4024178 & 0.68607324 & $p<0.01$ \\
\hline
\end{tabular}


Table II. Continued

\begin{tabular}{|c|c|c|c|c|c|}
\hline Accession & Description & \# AAs & MW [kDa] & Fold change & $\begin{array}{c}t \text {-test } \\
(p \text {-value })\end{array}$ \\
\hline P52735 & $\begin{array}{l}\text { Guanine nucleotide exchange factor VAV2 OS=Homo sapiens } \\
\text { GN=VAV2 } P E=1 \text { SV=2 - [VAV2_HUMAN] }\end{array}$ & 878 & 101.223761 & 0.68510642 & $p<0.001$ \\
\hline E9PCZ3 & $\begin{array}{l}\text { Type II inositol 3,4-bisphosphate 4-phosphatase (Fragment) } \\
\text { OS=Homo sapiens GN=INPP4B PE=4 SV=1 - [E9PCZ3_HUMAN] }\end{array}$ & 688 & 78.1047694 & 0.67949237 & $p<0.001$ \\
\hline P09382 & $\begin{array}{l}\text { Galectin-1 OS=Homo sapiens GN=LGALS1 PE=1 } \\
\text { SV=2 - [LEG1_HUMAN] }\end{array}$ & 135 & 14.7062001 & 0.67748938 & $p<0.001$ \\
\hline P48052 & $\begin{array}{l}\text { Carboxypeptidase A2 OS=Homo sapiens GN=CPA2 PE=1 } \\
\mathrm{SV}=3-\text { [CBPA2_HUMAN] }\end{array}$ & 419 & 47.0006266 & 0.67601541 & $p<0.01$ \\
\hline K7ERE3 & $\begin{array}{l}\text { Keratin, type I cytoskeletal } 13 \text { OS=Homo sapiens GN=KRT13 } \\
\mathrm{PE}=1 \mathrm{SV}=1-[\mathrm{K} 7 \mathrm{ERE} 3 \text { HUMAN] }\end{array}$ & 415 & 45.232239 & 0.66812005 & $p<0.001$ \\
\hline B3KUB4 & $\begin{array}{l}\text { Carbonic anhydrase } 12 \text { OS=Homo sapiens } \mathrm{GN}=\mathrm{CA} 12 \\
\mathrm{PE}=2 \mathrm{SV}=1-[\mathrm{B} 3 \mathrm{KUB} 4 \text { HUMAN] }\end{array}$ & 283 & 31.8373497 & 0.66653472 & $p<0.001$ \\
\hline Q5JVM0 & $\begin{array}{l}\text { Unconventional myosin-VI (Fragment) OS=Homo sapiens } \\
\text { GN=MYO6 PE }=1 \text { SV=1 - [Q5JVM0_HUMAN] }\end{array}$ & 174 & 20.5885602 & 0.66103342 & $p<0.001$ \\
\hline Q13451 & $\begin{array}{l}\text { Peptidyl-prolyl cis-trans isomerase FKBP5 OS=Homo sapiens } \\
\text { GN=FKBP5 PE }=1 \mathrm{SV}=2-[\text { FKBP5_HUMAN] }\end{array}$ & 457 & 51.1795705 & 0.66044757 & $p<0.001$ \\
\hline P21266 & $\begin{array}{l}\text { Glutathione S-transferase Mu } 3 \text { OS=Homo sapiens GN=GSTM3 } \\
\mathrm{PE}=1 \mathrm{SV}=3-[\mathrm{GSTM} 3 \text { _HUMAN] }\end{array}$ & 225 & 26.5421389 & 0.65763968 & $p<0.001$ \\
\hline F5GWT4 & $\begin{array}{l}\text { Serine/threonine-protein kinase WNK1 OS=Homo sapiens } \\
\text { GN=WNK1 PE }=1 \mathrm{SV}=1-[\text { F5GWT4_HUMAN] }\end{array}$ & 2,134 & 225.364792 & 0.65376951 & $p<0.01$ \\
\hline Q9BV86 & $\begin{array}{l}\text { N-terminal Xaa-Pro-Lys N-methyltransferase } 1 \text { OS=Homo sapiens } \\
\text { GN=NTMT1 PE=1 SV=3 - [NTM1A_HUMAN] }\end{array}$ & 223 & 25.3708399 & 0.65311967 & $p<0.001$ \\
\hline O14907 & $\begin{array}{l}\text { Tax1-binding protein } 3 \text { OS=Homo sapiens GN=TAX1BP3 } \\
\mathrm{PE}=1 \mathrm{SV}=2-[\mathrm{TX} 1 \mathrm{~B} 3 \text { HUMAN] }\end{array}$ & 124 & 13.7261295 & 0.62476735 & $p<0.001$ \\
\hline O14745 & $\begin{array}{l}\mathrm{Na}(+) / \mathrm{H}(+) \text { exchange regulatory cofactor NHE-RF1 } \\
\mathrm{OS}=\text { Homo sapiens } \mathrm{GN}=\mathrm{SLC} 9 \mathrm{~A} 3 \mathrm{R} 1 \mathrm{PE}=1 \mathrm{SV}=4-\left[\mathrm{NHRF} 1 \_ \text {HUMAN] }\right.\end{array}$ & 358 & 38.844612 & 0.6105772 & $p<0.001$ \\
\hline A0A096LPF0 & $\begin{array}{l}\text { Ras-related protein Rab-7b (Fragment) OS=Homo sapiens } \\
\text { GN=RAB7B PE=4 SV=1 - [A0A096LPF0_HUMAN] }\end{array}$ & 91 & 10.3803502 & 0.59567283 & $p<0.001$ \\
\hline Q8IVL1 & $\begin{array}{l}\text { Neuron navigator } 2 \text { OS=Homo sapiens GN=NAV2 PE }=1 \\
\text { SV=3 - [NAV2_HUMAN] }\end{array}$ & 2,488 & 268.002547 & 0.58546377 & $p<0.001$ \\
\hline Q9UKY7 & $\begin{array}{l}\text { Protein CDV3 homolog OS=Homo sapiens GN=CDV3 } \\
\mathrm{PE}=1 \mathrm{SV}=1-\left[\mathrm{CDV} 3 \_H U M A N\right]\end{array}$ & 258 & 27.3183615 & 0.56625057 & $p<0.001$ \\
\hline B4DEY6 & $\begin{array}{l}\text { LIM and cysteine-rich domains protein } 1 \text { OS=Homo sapiens } \\
\text { GN=LMCD1 } \mathrm{PE}=2 \mathrm{SV}=1 \text { - [B4DEY6_HUMAN] }\end{array}$ & 253 & 28.4947789 & 0.56611995 & $p<0.01$ \\
\hline P49006 & $\begin{array}{l}\text { MARCKS-related protein OS=Homo sapiens GN=MARCKSL1 } \\
\mathrm{PE}=1 \mathrm{SV}=2-[\text { MRP_HUMAN] }\end{array}$ & 195 & 19.5172325 & 0.56466249 & $p<0.01$ \\
\hline P36405 & $\begin{array}{l}\text { ADP-ribosylation factor-like protein } 3 \text { OS=Homo sapiens } \\
\text { GN=ARL3 PE }=1 \mathrm{SV}=2-[\text { ARL3_HUMAN] }\end{array}$ & 182 & 20.44276 & 0.56320138 & $p<0.001$ \\
\hline Q9Y2T7 & $\begin{array}{l}\text { Y-box-binding protein } 2 \text { OS=Homo sapiens } \mathrm{GN}=\mathrm{YBX} 2 \\
\mathrm{PE}=1 \mathrm{SV}=2-[\mathrm{YBOX} 2 \text { HUMAN] }\end{array}$ & 364 & 38.4947655 & 0.55489064 & $p<0.01$ \\
\hline H0YE40 & $\begin{array}{l}\text { CD44 antigen (Fragment) OS=Homo sapiens GN=CD44 } \\
\mathrm{PE}=1 \mathrm{SV}=1-[\text { H0YE40_HUMAN] }\end{array}$ & 82 & 9.09947282 & 0.51939027 & $p<0.001$ \\
\hline P06401 & $\begin{array}{l}\text { Progesterone receptor OS=Homo sapiens GN=PGR } \\
\mathrm{PE}=1 \mathrm{SV}=4-[\text { PRGR_HUMAN] }\end{array}$ & 933 & 98.9181716 & 0.5090052 & $p<0.001$ \\
\hline Q02790 & $\begin{array}{l}\text { Peptidyl-prolyl cis-trans isomerase FKBP4 OS=Homo sapiens } \\
\text { GN=FKBP4 PE=1 SV=3 - [FKBP4_HUMAN] }\end{array}$ & 459 & 51.7720738 & 0.48439102 & $p<0.001$ \\
\hline P08185 & $\begin{array}{l}\text { Corticosteroid-binding globulin OS=Homo sapiens } \\
\text { GN=SERPINA6 PE }=1 \text { SV=1 - [CBG_HUMAN] }\end{array}$ & 405 & 45.1119093 & 0.39363177 & $p<0.001$ \\
\hline Q9H993 & $\begin{array}{l}\text { UPF0364 protein C6orf211 OS=Homo sapiens } \\
\text { GN=C6orf211 PE=1 SV=1 - [CF211_HUMAN] }\end{array}$ & 441 & 51.1398629 & 0.37407832 & $p<0.001$ \\
\hline P02795 & $\begin{array}{l}\text { Metallothionein-2 OS=Homo sapiens GN=MT2A PE=1 } \\
\text { SV=1 - [MT2_HUMAN] }\end{array}$ & 61 & 6.0371964 & 0.33853248 & $p<0.001$ \\
\hline
\end{tabular}

were significantly increased while proteins involved in the $\mathrm{PI} 3 \mathrm{~K} / \mathrm{Akt} / \mathrm{mTOR}$ pathway (Akt and mTOR) were unchanged. It was interesting that signaling components of the Ras pathway (i.e., MEK and ERK1) were unchanged, while the downstream effectors (i.e., RSK1 and RSK2) of the Ras and p38/MAPK pathway were the predominant kinases that were increased. In general, RSK phosphorylates various substrates that control diverse cellular processes and when inhibited, it 


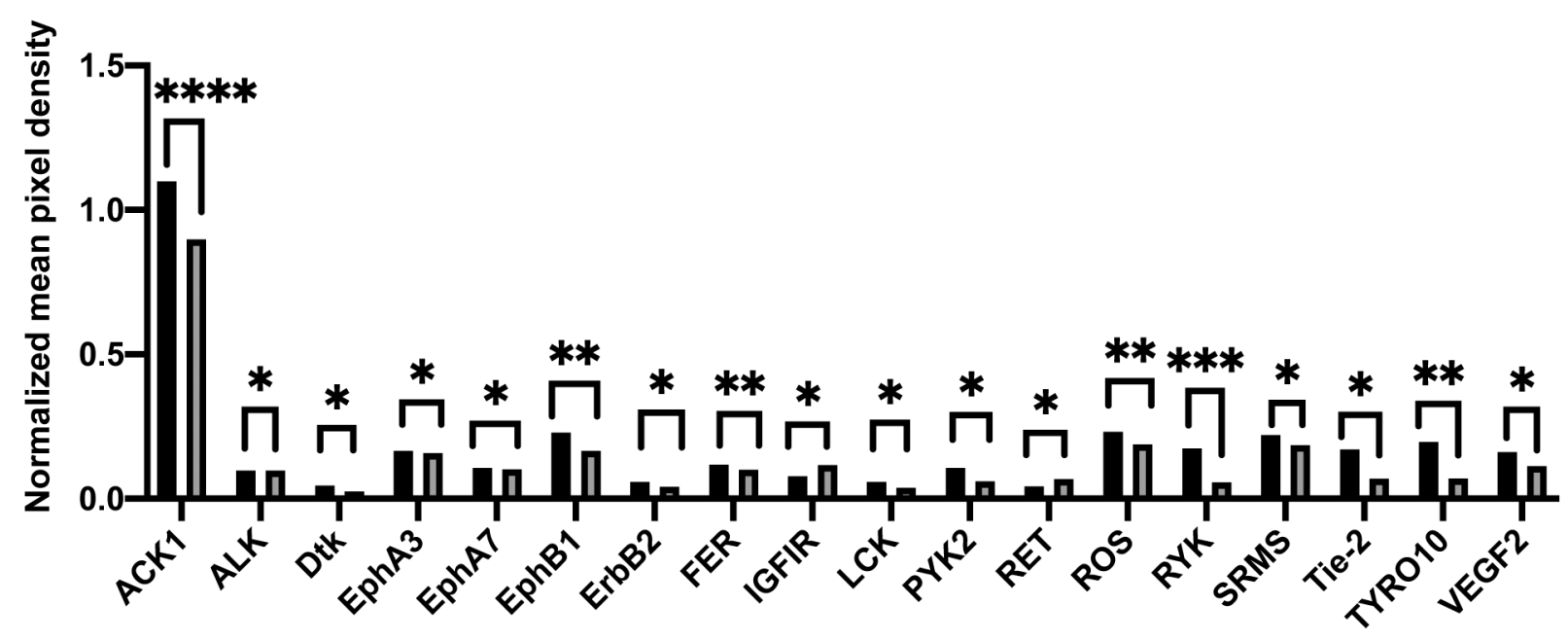

Receptor tyrosine kinases

T47Darom

T47DaromLR

Figure 2. Hormone dependent letrozole resistance induces global down-regulation of activated receptor tyrosine kinases. Graph depict normalized mean pixel density of protein levels in lysates prepared from the T47Darom and T47DaromLR cells using the Human RTK Antibody Array Membrane where 71 different anti-RTK antibodies were spotted in duplicated, including 4 positive and 3 negative controls and 1 blank. Array signals were analyzed using Image Lab (BioRad) software. Values from duplicate spots were averaged and plotted. Results are expressed as the mean unit \pm SD $(* * * * p<0.0001, * * * p<0.001, * * p<0.01, * p<0.05)$.

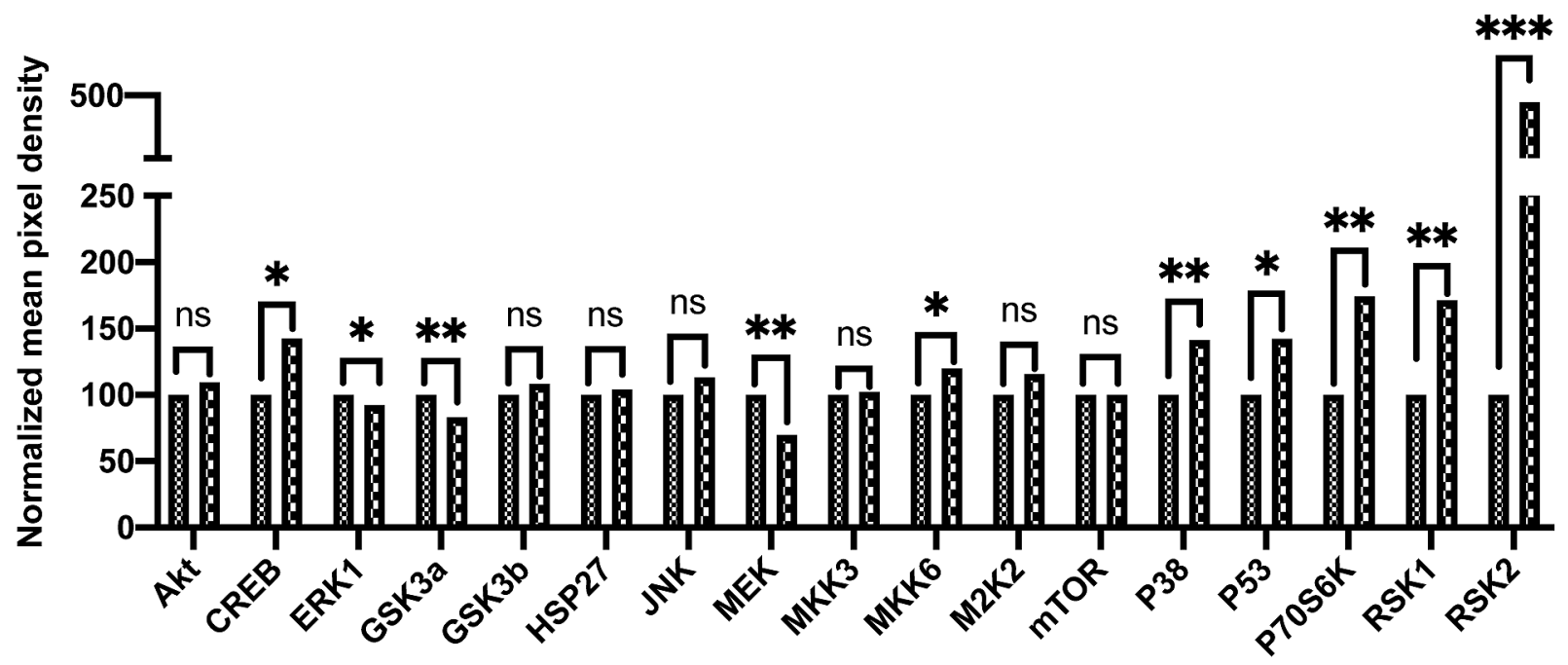

MAPK pathway phospho proteins

\% T47Darom

Ex T47DaromLR

Figure 3. MAPK signaling cascade is induced in the letrozole-resistant T47DaromLR cells. Graph depict normalized mean pixel density of protein levels in lysates prepared from the T47Darom and T47DaromLR cells using the Human MAPK Phosphorylation Antibody Array Membrane where 17 different anti-MAPK related antibodies were spotted in duplicate, including 4 positive and 3 negative controls and 1 blank. Array signals were analyzed using Image Lab (BioRad) software. Values from duplicate spots were averaged and plotted. Results are expressed as the mean unit \pm SD $(* * * p<0.001, * * p<0.01, * p<0.05)$. 

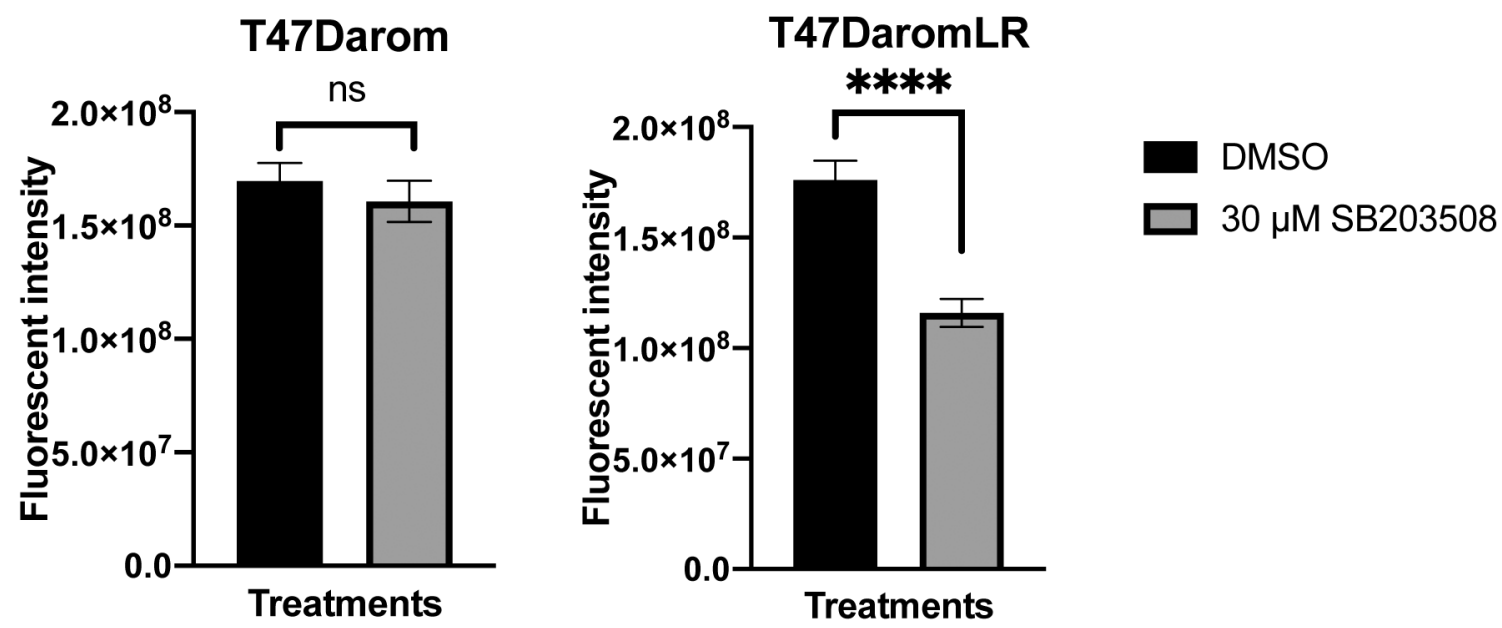

Figure 4. Letrozole resistant cells are more sensitive to the growth inhibitory effects of p38/MAPK inhibitor SB 203508. The T47Darom cells were cultured in standard growth media and transferred to phenol red free media for two days prior to treatment with DMSO control or $30 \mu M$ of SB 203508 and cell proliferation assays were performed after $24 \mathrm{~h}$. Proliferation was measured using the resazurin assay and graphs depict the fluorescence intensity of cells read at $430 / 560 \mathrm{nM}$ wavelengths. Results are expressed as the mean unit $\pm S D(* * * * p<0.0001)$ of three independent experiments in triplicate; ns: not significant.

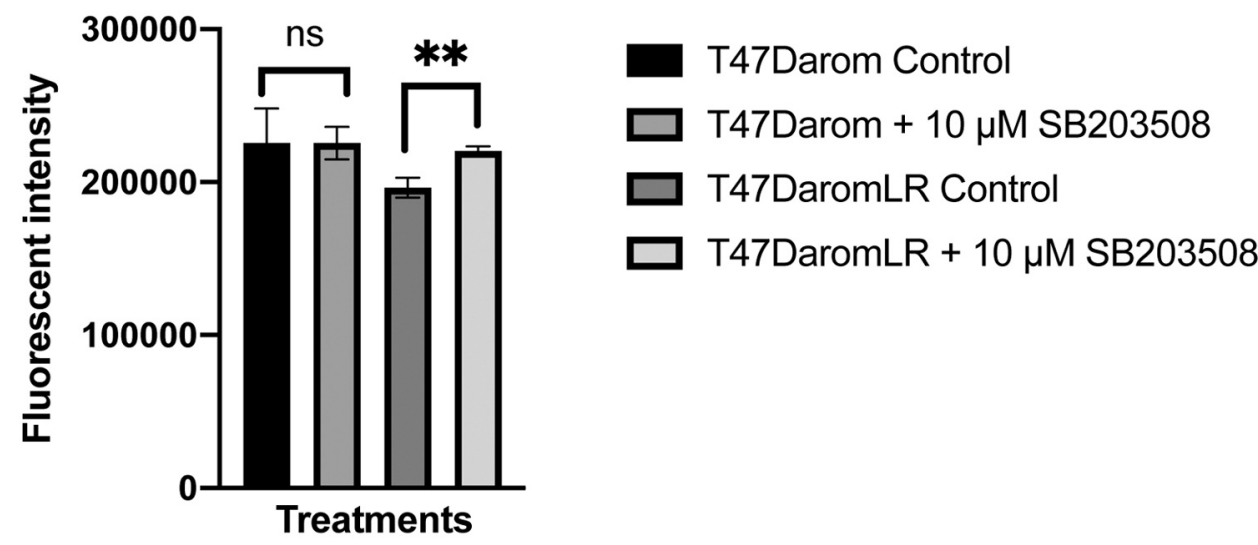

Figure 5. Induction of apoptosis through targeting p38. The T47Darom cells were cultured in standard growth media and transferred to phenol red free media for two days prior to treatment with DMSO control or $10 \mu M$ of SB 203508 and caspase 3/7 activity was assessed by measuring the fluorescent intensity of cells at 530/502 $\mathrm{nM}$ wavelength. Results are expressed as the mean unit $\pm S D(* * p<0.01)$ of three independent experiments in triplicate.

eliminates breast tumor initiating cells which are de novo chemo-resistant (16). Given these findings, it is likely that ERdependent AI resistance is mediated through the p38/MAPK signaling cascade. The observation that the MAPK signaling was increased in the T47DaromLR cells was not completely novel, since it has been previously reported that HER2, p-Shc, Grb2, and the signaling proteins in the MAPK cascade were increased in the LTLT-Ca cells (1).

A global proteomic analysis was conducted using the T47Darom and the T47DaromLR cells to further identify a protein signature specifically associated with ER+ AI resistance. Since we identified that acquired resistance was associated with the p38/MAPK signaling cascade, it is notable that one of the upstream signaling molecules, MAP3K6 was up-regulated. Out of a total of 127 significantly increased proteins, MAP3K6 exhibited the highest expression and was associated with decreased relapse-free survival. This further underscored the aggressive nature of breast tumors fitting this profile. Based on these findings, it is likely that as letrozole sensitive cells transition to a letrozole resistant phenotype they preferentially proliferate through activation of the p38/MAPK pathway 
inducing phosphorylation of RSK1/RSK2. Failure of these cells to respond to tamoxifen suggests they may utilize additional ligand independent signaling mechanism potentiated by $\mathrm{p} 38$. When the cells were treated with a $\mathrm{p} 38$ inhibitor, the T47Darom cells exhibited decreased proliferation and a slight induction in apoptosis.

While the major focus of this study was the p38/MAPK pathway, other proteins were identified including a protein disulfide isomerase (PDI) P4HB (prolyl 4-hydroxylase b). During times of oxidative stress or endoplasmic reticulum stress proteins unfold and molecular chaperones, like P4HB, assist in restoring unfolded proteins to their native conformation (17). A previous report has found that $\mathrm{P} 4 \mathrm{HB}$ promoted a malignant phenotype in glioma cells via MAPK signaling (18) and identified $\mathrm{P} 4 \mathrm{HB}$ as a novel target of chemoresistance in glioblastoma multiforme (19). It was hypothesized that perturbation of $\mathrm{P} 4 \mathrm{HB}$ may sensitize the chemo-resistant glioma cells. While it is also known that PDIs serve as molecular chaperones to maintain ER $\alpha$ structure and function (20), the significance of high levels of $\mathrm{P} 4 \mathrm{HB}$ and/or convergence with MAPK signaling pathways in AI-resistance remains unclear.

The proteomic analysis also revealed increased midasin (MDN1) expression which functions as a nuclear chaperone that is involved in the assembly/disassembly of macromolecular complexes in the nucleus, and is associated with maturation of $60 \mathrm{~S}$ ribosome subunits (21). The finding that midasin was overexpressed in the T47DaromLR cells was interesting because a previous proteomic analysis demonstrated a 35-fold increase in MDN1 expression in LTLT-Ca cells cultured as mammospheres compared to LTLT-Ca cells cultured adherently $(22,23)$. While the role of midasin in breast cancer remains unclear, it is known that ribosomal biogenesis remains at the heart of translation. This process requires extensive regulation and coordination to meet the cellular demands of continuous ribosome production and aberrant midasin expression and subsequent interference with ribosomal biogenesis affects translation and the overall fitness of the cell.

While the proteomic signature of ER+ AI resistance is associated with enhanced p38/MAPK signaling there are additional factors contributing to this phenotype that are yet to be understood. Future studies will allow understanding how various signaling cascades converge to induce acquired letrozole resistance.

\section{Conflicts of Interest}

The Authors declare no conflicts of interest in relation to this study.

\section{Authors' Contributions}

SLT conceived and designed the experiments and directed the project. RRW and MRB performed the experiments. AMD, KPL, and GW contributed to data acquisition. RRW, KZ, and KMG analyzed and interpreted the data. AMD provided technical editing. RRW and SLT wrote the manuscript.

\section{Acknowledgements}

The Authors thank the ITT Research Institute and Dr. Akash Gupta for generously donating the T47Darom and T47DaromLR cell lines.

\section{Funding}

This work was supported in part by the National Institutes of Health [grant number 1SC1GM126617] awarded to Syreeta L. Tilghman. This publication was made possible by funding from the Louisiana Cancer Research Consortium and the National Institutes of Health Research Centers at Minority Institutes [grant numbers 8G12MD007595 and U54MD007582] from the National Institute on Minority Health and Health Disparities. The contents are solely the responsibility of the authors and do not necessarily represent the official views of the Louisiana Cancer Research Consortium or the NIH.

\section{References}

1 Jelovac D, Sabnis G, Long BJ, Macedo L, Goloubeva OG and Brodie AM: Activation of mitogen-activated protein kinase in xenografts and cells during prolonged treatment with aromatase inhibitor letrozole. Cancer Res 65(12): 5380-5389, 2005. PMID: 15958587. DOI: 10.1158/0008-5472.can-04-4502

2 Tilghman SL, Townley I, Zhong Q, Carriere PP, Zou J, Llopis SD, Preyan LC, Williams CC, Skripnikova E, Bratton MR, Zhang Q and Wang G: Proteomic signatures of acquired letrozole resistance in breast cancer: Suppressed estrogen signaling and increased cell motility and invasiveness. Mol Cell Proteomics 12(9): 2440-2455, 2013. PMID: 3769322. DOI: 10.1074/mcp.M112.023861

3 Gupta A, Mehta R, Alimirah F, Peng X, Murillo G, Wiehle R and Mehta RG: Efficacy and mechanism of action of proellex, an antiprogestin in aromatase overexpressing and letrozole resistant T47D breast cancer cells. J Steroid Biochem Mol Biol 133: 30-42, 2013. PMID: 22939887. DOI: 10.1016/j.jsbmb. 2012.08.004

4 Györffy B, Lanczky A, Eklund AC, Denkert C, Budczies J, Li Q and Szallasi Z: An online survival analysis tool to rapidly assess the effect of 22,277 genes on breast cancer prognosis using microarray data of 1,809 patients. Breast Cancer Res Treat 123(3): 725-731, 2010. PMID: 20020197. DOI: 10.1007/s10549-009-0674-9

5 Johnson KP, Yearby LA, Stoute D, Burow ME, Rhodes LV, Gray M, Carriere P, Tilghman SL, McLachlan JA and Ochieng J: In vitro and in vivo evaluation of novel anticancer agents in triple negative breast cancer models. J Health Care Poor Underserved 24: 104-111, 2013. PMID: 3628744. DOI: 10.1353/hpu.2013.0047

6 Walker RR, Patel J, Davidson AM, and Tilghman SL: A novel phytoalexin, glyceollins, trigger anti-proliferative effects in aromatase inhibitor resistant breast cancer. Cancer Res 80(16 Suppl): Abstract 4116, 2020. DOI: 10.1158/1538-7445.AM2020-4116

7 Sabnis G and Brodie A: Adaptive changes results in activation of alternate signaling pathways and resistance to aromatase inhibitor resistance. Mol Cell Endocrinol 340(2): 142-147, 2011. PMID: 20849912. DOI: 10.1016/j.mce.2010.09.005 
8 Lotem J and Sachs L: A mutant p53 antagonizes the deregulated c-myc-mediated enhancement of apoptosis and decrease in leukemogenicity. Proc Natl Acad Sci USA 92(21): 9672-9676, 1995. PMID: 7568195. DOI: 10.1073/pnas.92.21.9672

9 Li R, Sutphin PD, Schwartz D, Matas D, Almog N, Wolkowicz R, Goldfinger N, Pei H, Prokocimer M and Rotter V: Mutant p53 protein expression interferes with p53-independent apoptotic pathways. Oncogene 16(25): 3269-3277, 1998. PMID: 9681826. DOI: $10.1038 /$ sj.onc.1201867

10 Blandino G, Levine AJ and Oren M: Mutant p53 gain of function: Differential effects of different p53 mutants on resistance of cultured cells to chemotherapy. Oncogene 18(2): 477-485, 1999. PMID: 9927204. DOI: 10.1038/sj.onc.1202314

11 Bergamaschi D, Gasco M, Hiller L, Sullivan A, Syed N, Trigiante G, Yulug I, Merlano M, Numico G, Comino A, Attard M, Reelfs O, Gusterson B, Bell AK, Heath V, Tavassoli M, Farrell PJ, Smith P, Lu X and Crook T: P53 polymorphism influences response in cancer chemotherapy via modulation of p73-dependent apoptosis. Cancer Cell 3(4): 387-402, 2003. PMID: 12726864. DOI: 10.1016/s1535-6108(03)00079-5

12 Matas D, Sigal A, Stambolsky P, Milyavsky M, Weisz L, Schwartz D, Goldfinger $\mathrm{N}$ and Rotter V: Integrity of the $\mathrm{n}$ terminal transcription domain of p53 is required for mutant p53 interference with drug-induced apoptosis. EMBO J 20(15): 41634172, 2001. PMID: 11483519. DOI: 10.1093/emboj/20.15.4163

13 Murphy KL, Dennis AP and Rosen JM: A gain of function p53 mutant promotes both genomic instability and cell survival in a novel p53-null mammary epithelial cell model. FASEB J 14(14): 2291-2302, 2000. PMID: 11053251. DOI: 10.1096/fj.00-0128com

14 Aas T, Børresen AL, Geisler S, Smith-Sørensen B, Johnsen H, Varhaug JE, Akslen LA and Lønning PE: Specific p53 mutations are associated with de novo resistance to doxorubicin in breast cancer patients. Nat Med 2(7): 811-814, 1996. PMID: 8673929. DOI: $10.1038 / \mathrm{nm} 0796-811$

15 Sabnis G, Schayowitz A, Goloubeva O, Macedo L and Brodie A: Trastuzumab reverses letrozole resistance and amplifies the sensitivity of breast cancer cells to estrogen. Cancer Res 69(4): 1416-1428, 2009. PMID: 2644349. DOI: 10.1158/00085472.can-08-0857

16 Stratford AL, Reipas K, Hu K, Fotovati A, Brough R, Frankum J, Takhar M, Watson P, Ashworth A, Lord CJ, Lasham A, Print CG and Dunn SE: Targeting p90 ribosomal s6 kinase eliminates tumor-initiating cells by inactivating y-box binding protein- 1 in triple-negative breast cancers. Stem Cells 30(7): 1338-1348, 2012. PMID: 22674792. DOI: 10.1002/stem.1128
17 Noiva R: Protein disulfide isomerase: The multifunctional redox chaperone of the endoplasmic reticulum. Semin Cell Dev Biol 10(5): 481-493, 1999. PMID: 10597631. DOI: 10.1006/scdb.1999.0319

18 Sun S, Kiang KMY, Ho ASW, Lee D, Poon MW, Xu FF, Pu JKS, Kan ANC, Lee NPY, Liu XB, Man K, Day PJR, Lui WM, Fung CF and Leung GKK: Endoplasmic reticulum chaperone prolyl 4hydroxylase, beta polypeptide $(\mathrm{p} 4 \mathrm{hb})$ promotes malignant phenotypes in glioma via mapk signaling. Oncotarget 8(42): 7191171923, 2017. PMID: 29069756. DOI: 10.18632/oncotarget.18026

19 Sun S, Lee D, Ho AS, Pu JK, Zhang XQ, Lee NP, Day PJ, Lui WM, Fung $\mathrm{CF}$ and Leung GK: Inhibition of prolyl 4hydroxylase, beta polypeptide (P4HB) attenuates temozolomide resistance in malignant glioma via the endoplasmic reticulum stress response (ERSR) pathways. Neuro Oncol 15(5): 562-577, 2013. PMID: 23444257. DOI: 10.1093/neuonc/not005

20 Schultz-Norton JR, McDonald WH, Yates JR and Nardulli AM: Protein disulfide isomerase serves as a molecular chaperone to maintain estrogen receptor alpha structure and function. Mol Endocrinol 20(9): 1982-1995, 2006. PMID: 16690750. DOI: 10.1210/me.2006-0006

21 Garbarino JE and Gibbons IR: Expression and genomic analysis of midasin, a novel and highly conserved aaa protein distantly related to dynein. BMC Genomics 3: 18, 2002. PMID: 12102729.

22 Tilghman SL, Pratt J, Llopis SD, Davidson AM, Walker RR, Carriere P, Davenport IR, Zhang W and Zhang K: Abstract 3183: Proteomic characterization of aromatase inhibitor resistant mammospheres reveal the presence of a novel nuclear chaperone. Cancer Res 77, 2017. DOI: 10.1158/1538-7445.AM2017-3183

23 Gallegos KM, Patel JR, Llopis SD, Walker RR, Davidson AM, Zhang W, Zhang K, and Tilghman SL: Quantitative proteomic profiling identifies a potential novel chaperone marker in resistant breast cancer. Front Oncol 2021 [epub ahead of print]. DOI: 10.3389/fonc. 2021.540134
Received November 30, 2020

Revised December 31, 2020

Accepted January 4, 2021 